\title{
Review
}

\section{Recent developments on the South American monsoon system}

\author{
J. A. Marengo, ${ }^{\text {a }}$ B. Liebmann, ${ }^{\mathrm{b}}$ A. M. Grimm, ${ }^{\mathrm{c}}$ V. Misra, ${ }^{\mathrm{d}}$ P. L. Silva Dias, ${ }^{\mathrm{e}}$ \\ I. F. A. Cavalcanti, ${ }^{\mathrm{f}}$ L. M. V. Carvalho, ${ }^{\text {g }}$ E. H. Berbery, ${ }^{\mathrm{h}}$ T. Ambrizzi, ${ }^{\mathrm{e}}$ C. S. Vera, \\ A. C. Saulo, ${ }^{i}$ J. Nogues-Paegle, ${ }^{j}$ E. Zipser ${ }^{j}$ A. Seth ${ }^{k}$ and L. M. Alves ${ }^{\mathrm{e}}$ \\ a CCST-INPE, Rodovia Dutra Km 40, 12630-000 Cachoeira Paulista, São Paulo, Brazil \\ b CIRES NOAA, Boulder, Colorado, USA \\ ${ }^{c}$ Federal University of Paraná, Curitiba, Paraná, Brazil \\ ${ }^{d}$ Florida State University, Tallahassee, Florida, USA \\ ${ }^{\mathrm{e}}$ University of São Paulo, São Paulo, Brazil \\ ${ }^{f}$ CPTEC-INPE, Rodovia Dutra Km 40, 12630-000 Cachoeira Paulista, São Paulo, Brazil \\ ${ }^{g}$ University of California, Santa Barbara, California, USA \\ ${ }^{\text {h }}$ University of Maryland, College Park, Maryland, USA

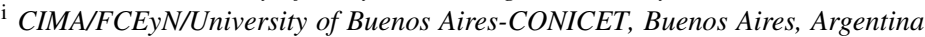 \\ j University of Utah, Salt Lake City, Utah, USA \\ ${ }^{\mathrm{k}}$ University of Connecticut, Hartford, Connecticut, USA
}

\begin{abstract}
This paper reviews recent progress made in our understanding of the functioning and variability of the South American Monsoon System (SAMS) on time scales varying from synoptic to long-term variability and climate change. The SAMS contains one of the most prominent summertime climate patterns in South America, featuring a strong seasonal variability in a region lying between the Amazon and the La Plata Basin. Much of the recent progress is derived from complementary international programs, such as the Monsoon Experiment South America (MESA), as well as from ongoing international programs such as the Large Scale Biosphere Atmosphere Experiment in the Amazon Basin (LBA) and the La Plata Basin (LPB) Regional Hydroclimate Project, which includes the CLARIS LPB Europe-South America Network for Climate Change Assessment and Impact Studies in La Plata Basin Project. The latter assesses atmosphere-land surface interactions, the role of land use changes and aerosols from biomass burning considered as sources of variability and change in the SAMS functioning, characteristics and behaviour.

The SAMS region is particularly susceptible to variations of climate due to the importance of hydroelectricity generation and the agricultural base of local economies. Also addressed in this report are projections of climate change and extremes, which are important for impact and vulnerability assessments. This discussion includes the need to identify and understand important processes that control the monsoonal climate, how these processes may vary and change, and how they may interact with key societal sectors, including water resource management, hydroelectric generation, agriculture, and agribusiness.

This paper reports on the major contributions of MESA to the knowledge of characteristics, functioning and variability of the SAMS, and is based on recent studies and publications, and can be considered as an update of a previous review by C. S. Vera et al. (2006a). Copyright (c) 2010 Royal Meteorological Society
\end{abstract}

KEY WORDS South American monsoon; climate change; climate variability

Received 21 December 2009; Revised 2 September 2010; Accepted 13 October 2010

\section{Introduction}

The South American Monsoon System (SAMS) encompasses most of South America, featuring strong seasonal variability in a region lying between the Amazon and the La Plata Basin. The life cycle and variations of SAMS are significantly influenced by many factors, including

* Correspondence to: J. A. Marengo, CCST-INPE, Rodovia Dutra km, 40, 12630-000 Cachoeira Paulista, Sao Paulo, Brazil.

E-mail: jose.marengo@inpe.br variability in various time scales in the adjacent Pacific and Atlantic Oceans, the Andean and central-east Brazil topography, complex land surface processes and relations with land use change, and interactions involving topography and soil moisture.

Various comprehensive studies and earlier reviews on the South American Monsoon System (Grimm et al. 2005; Vera et al. 2006a; Garcia and Kayano 2008; Liebmann and Mechoso 2010; Gan et al. 2009; Grimm and Silva Dias 2010; and references cited within) have 
indentified the major characteristics and functioning of the SAMS on various time scales.

International programs such as the Monsoon Experiment in South America (MESA; www.clivar.org/vamos) from the World Climate Research Programme-Climate Variability and Predictability (WCRP CLIVAR) panel on the Variability of American Monsoon Systems (VAMOS) have prompted many observational and modelling studies of climate and hydrology variability on various time scales, from intra-seasonal to multi-decadal, including climate change. The main objectives of this article are to present the progress made in studies of the South American Monsoon since Vera et al. (2006a) and to discuss MESA's contributions to the knowledge of climate in the region.

Recent MESA advances in understanding SAMS include new insights about: (1) the moisture transport processes between the tropics and extra-tropics; (2) the structure and variability of the low-level jet east of the Andes; (3) the role of remote and local forcing in the inter-annual and decadal variability of the monsoon; (4) the diurnal cycle of precipitation and convection in the core monsoon regions; (5) the onset of the monsoon and its variability; (6) the mesoscale convective systems and their associations with low-level jet and heavy precipitation; (7) the role of land use changes and aerosol concentration on the onset and variability of the monsoon; and (8) projections of long-term changes in the monsoon characteristics and extremes. In addition, MESA is working to better predict SAMS variations on scales from daily to seasonal and decadal, as well as to investigate the potential impacts of climate change on the SAMS and related extreme events through improved understanding of this monsoon phenomenon.

This paper represents a comprehensive discussion of these 'grand issues'. Basing mostly on recent literature, the discussion constitutes a review and update of the current knowledge of the characteristics and functioning of the SAMS.

As much of this study relies on observational data, it is relevant to note that station precipitation data are not well distributed over South America, being particularly sparse in the central continent and more abundant in the east. Besides, long time series of station data are few. These drawbacks impose limitations on the studies of climate variability impacts pertaining to geographical coverage, and usually demand compromise between spatial and temporal coverage. The irregular distribution has sometimes been eased by gridding the data, but even so, the variability in certain regions may not be well represented. Furthermore, there are errors in some of the station precipitation data (zeros in place of missing data, periods of data copied from one station to another one, unrealistic values, etc.) that must be corrected before the data can be reliably used. Despite these problems, the observed data are still more reliable than proxies in characterising the climatology and the climate variability in South America, and further work in retrieving and correcting them should be carried out.

\section{Main structure and life cycle of the SAMS}

\subsection{Main structure}

The SAMS is part of the monsoon system of the Americas. In the upper troposphere, the wet summer season is characterised by an anticyclonic circulation over Bolivia and a trough over the tropical and sub-tropical South Atlantic, near the coast of Northeast Brazil (Figure 1A). Prominent low-level features include: (1) surface highpressure systems and anticyclonic circulation over the sub-tropical oceans (Pacific and Atlantic); (2) the Chaco thermal low centred over northern Argentina; (3) the South Atlantic Convergence Zone (SACZ); and (4) the South American Low-Level jet east of the Andes (SALLJ), a low-level northwesterly flow east of the Andes that extends from the southwestern Amazon to southeastern South America (SESA) (Figure 1B, D).

The Bolivian High has been explained as the response of diabatic local heating in the Amazon region. The establishment of the SACZ is a hallmark of the mature monsoon across South America. Transient moisture flux from the Amazon is important for maintenance of the SACZ, and the location of the SACZ is influenced by the topography in central-east Brazil while it has a strong influence on the position and intensity of the Bolivian High (Vera et al. 2006a). According to modelling studies, an absence of this topography would cause a southward shift of the SACZ (Grimm et al. 2007a).

Climate variability associated with the SACZ and the SALLJ dipole-like pattern has been indentified in various timescales, ranging from the intra-seasonal to the interdecadal (Nogués-Paegle and Mo 1997 on intra-seasonal time scales; Grimm and Zilli 2009 and Grimm 2010 on inter-annual time scale). One phase of the dipole is characterised by an enhanced SACZ and suppressed convection to the south, whereas the other phase is characterised by a suppressed SACZ and increased convection in the sub-tropical plains. A strengthening of the SALLJ and associated transports of massive amounts of moisture from the Amazon Basin into the sub-tropics accompanies the latter phase (Silva and Berbery, 2006, and references cited within). Strong SALLJ events are linked to shortterm extreme precipitation events in the plains of central Argentina (Liebmann et al. 2004; Salio et al. 2007). On the other hand, a SACZ-enhanced phase induces extreme heat waves over the sub-tropical regions (Cerne and Vera 2010). SALLJ events characterised by enhanced southward low-level wind and by a strong impact on precipitation over northern Argentina have been identified as Chaco jet events (CJEs).

Several studies have investigated Mesoscale Convective Systems (MCSs) in sub-tropical South America (Zipser et al., 2006; Salio et al., 2007; Durkee and Mote 2009, and references cited within). MCSs are composed of individual thunderstorms organised as a largerscale weather system with a contiguous precipitation area. Heavy rainfall from MCSs is often associated with floods, which can be disastrous to livestock, crops, and 

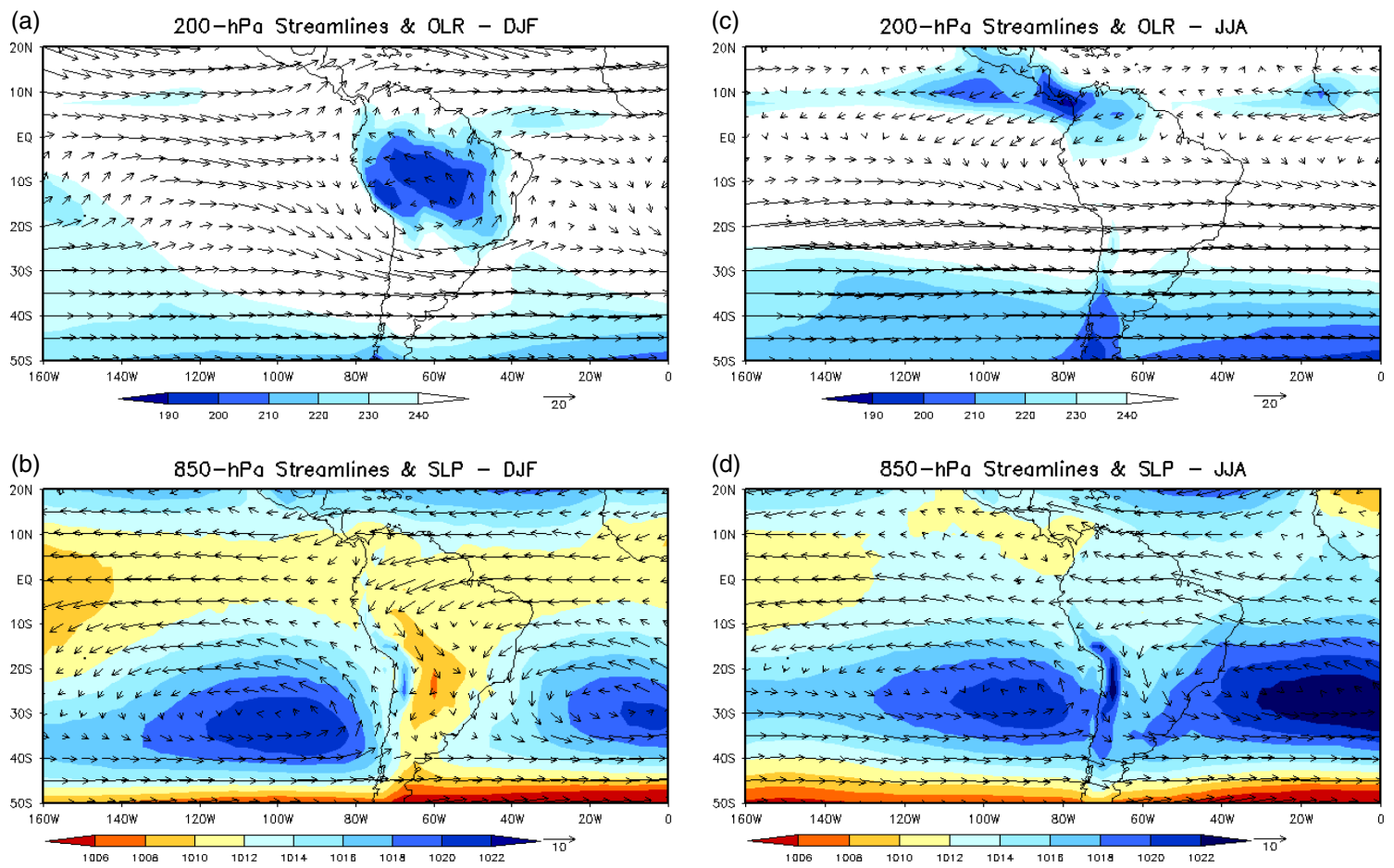

Figure 1. Mean (1979-2008) 200-hPa wind vector and outgoing longwave radiation (OLR) (top) and 850-hPa wind vector and sea level pressure (SLP) (bottom), for DJF and JJA. Units are $\mathrm{W} \mathrm{m}-2$ for OLR and $\mathrm{hPa}$ for SLP. Circulation data are derived from the NCEP/NCAR Reanalysis. This figure is available in colour online at wileyonlinelibrary.com/journal/joc

humankind. However, the majority of those studies are limited in temporal scope to a few years.

Recent studies (Durkee et al. 2009) have shown that Mesoscale Convective Complexes MCCs (a type of MCSs) in sub-tropical South America are larger and longer lived than previous studies. Compared with the MCCs in the United States, MCCs in southern South America are significantly larger with longer durations and do not exhibit much poleward migration throughout the warm season. MCCs are more frequent east of the Andes Mountains between 20 and $30^{\circ} \mathrm{S}$ over the La Plata Basin; the greatest impacts on precipitation anomalies from MCC rainfall were located near the centre of the La Plata Basin. Ultimately, MCCs in sub-tropical South America are large, long-lasting events with great potential for contributing significantly to precipitation totals across the region.

\subsection{Life cycle}

The annual cycle of upper tropospheric circulation features over South America (Figure 2A-D) is strongly linked to the seasonally varying horizontal SST and surface temperature gradients, which arise from differential heating due to the difference in thermal capacity between land and water. A direct thermal circulation results from this difference, with low-level (upper-level) convergence (divergence), mid-tropospheric rising motion and precipitation over the continent, and low-level (upperlevel) divergence (convergence), mid-tropospheric sinking motion and dry conditions over the neighbouring oceanic areas, varying in position during austral summer (DJF) and winter (JJA).
The precipitation annual cycle features distinct wet and dry seasons between the equator and $25^{\circ} \mathrm{S}$. Many areas within that region receive more (less) than 50\% (5\%) of their total annual precipitation during the austral summer (winter) (Figure 3). The peak of the rainy season in the southern Amazonia SAMS region and in southeastern Brazil occurs in December through February, although in the northwestern and central Amazon the wet season peaks somewhat later (March-May). Near the equator in the western Amazon Basin, rainfall is plentiful yearround, even though there is a near-doubling from the driest (November) to the wettest (May) month (cf. Figure 1 in Grimm 2010).

The largest contrasts between summer and winter rainfall are observed in the central Amazon Basin at about $10^{\circ} \mathrm{S}$, with almost all rainfall occurring in the summer season (Figure 3). The SACZ is considered a southeastward extension of the wet season maximum at $10^{\circ} \mathrm{S}$. Satellite-derived estimates of rainfall in the SACZ show that the mean precipitation can be as strong over the ocean as it is over land at any given time (Carvalho et al. 2004). Over southern Brazil, southeastern Paraguay and northeastern Argentina, rainfall is nearly evenly distributed throughout the year (cf. Figure 1 in Grimm 2010).

\section{Development of SAMS: onset}

Onset of SAMS has been defined based on changes in precipitation, OLR, cloudiness, synoptic-scale flow fields, thermodynamic parameters, land surface conditions, or a 
(a) West-East Divergent Circulation (DJF) Mean (10-20S)

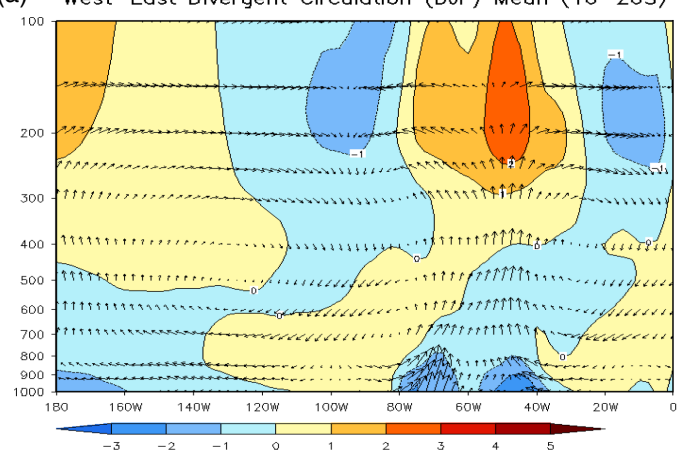

(b) North-South Divergent Circulation (DJF) Mean (70w-40W)

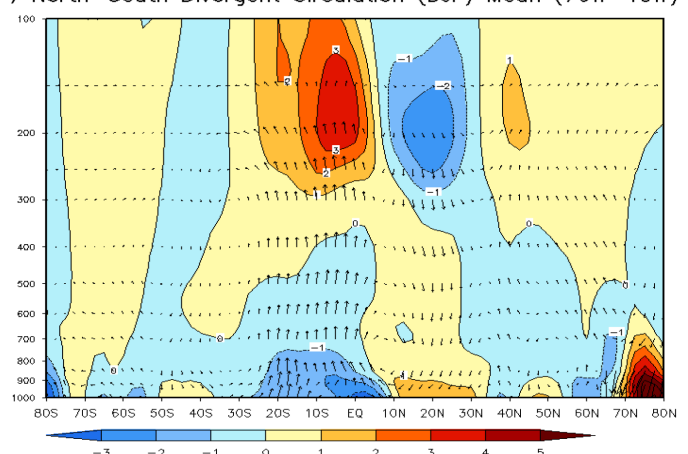

(c) West-East Divergent Circulation (JJA) Mean (10-20S)

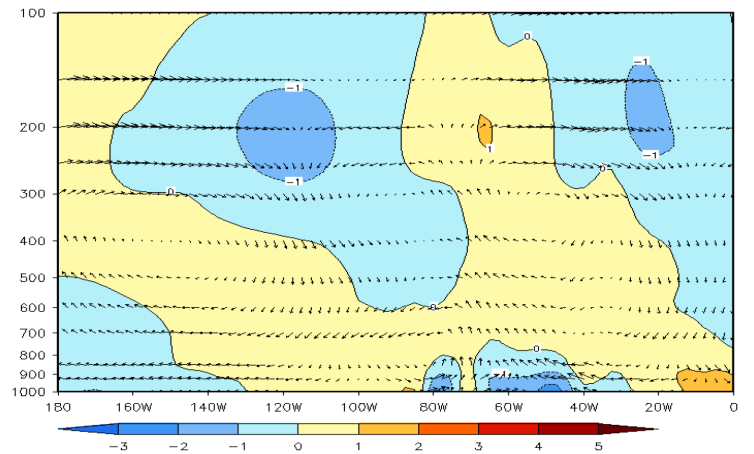

(1)

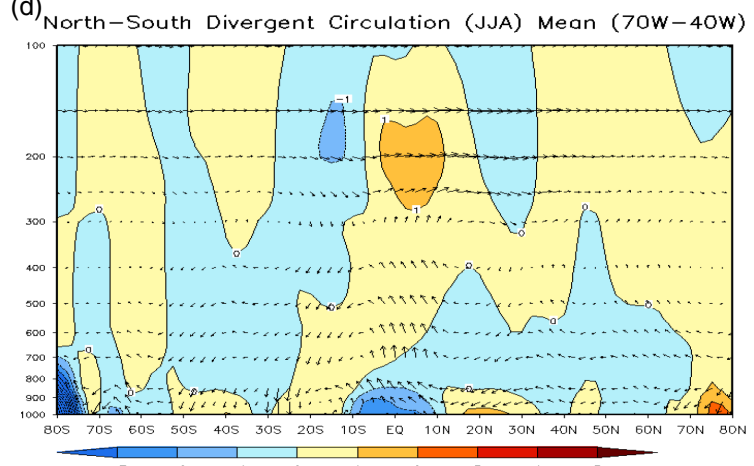

Figure 2. Vertical-longitude cross-section of the mean (1979-2008) divergent circulation (vectors) for the latitude band $10-20{ }^{\circ} \mathrm{S}$ (top panels) and for the longitude band $70-40^{\circ} \mathrm{W}$ (lower panels). Units are $10^{-6} \mathrm{~s}^{-1}$ for divergence (contours and shading). a) and b) are for austral summer DJF and c) and d) are for austral winter IIA. This figure is available in colour online at wileyonlinelibrary.com/journal/joc

combination of them (Gan et al. 2006; Gonzales et al., 2007; Silva and Carvalho, 2007; Raia and Cavalcanti, 2008; Garcia and Kayano, 2009; Nieto-Ferreira and Rickenbach, 2011; Nieto-Ferreira et al., 2011, and references cited therein).

Gonzalez et al. (2007) applied Kousky's (1988) OLR technique to the entire SAMS region, and found an earlier onset (about 7 pentads earlier) than the onset derived from ECMWF reanalysis data ( $\mathrm{Li}$ and $\mathrm{Fu} 2004)$, and about 3 pentads earlier than the onset derived from precipitation data by Marengo et al. (2001).

Silva and Carvalho (2007) defined the Large-Scale Index for South American Monsoon (LISAM) to establish the onset and end of SAMS. LISAM is based on a combined empirical orthogonal function (EOF) analysis of precipitation and various thermodynamic and dynamic low-level fields linked to the onset and end of the monsoon rainy season. The zonal wind indicator of Gan et al. (2006) suggests an earlier onset and end than does LISAM. Onset from the index proposed by Raia and Cavalcanti (2008) using moisture flux is similar to that from LISAM, except the ending date is earlier.

Different indices may indicate slight differences in the starting or ending time of the onset, but a general picture emerges: The development of the SAMS during the austral spring is characterised by a rapid southward shift of the region of intense convection from the Caribbean and northwestern South America to the southern Amazon Basin and Brazilian highlands (Planalto) in October and to southeast Brazil in November. At onset, the
South Atlantic High moves eastward, reflecting the pressure reduction over the continent and the intensity and direction of the zonal flow over the nearby tropics and sub-tropics. The southward moisture flux east of the Andes increases, bringing humidity to central and southeast Brazil.

Gonzalez et al. (2007) suggested that transient activity, which occurs when the atmospheric mean conditions become less stable as summer approaches, imprints a rainfall-jump feature in the monsoon precipitation evolution. Cold fronts may play a similar role in the SAMS onset. Li and Fu (2004) and Raia and Cavalcanti (2008) proposed that cold fronts may help trigger monsoon onset by enhancing forced ascent in a thermodynamically primed atmosphere. Raia and Cavalcanti (2008) found that a low-frequency (intra-seasonal timescale) upstream blocking pattern in the upper-level atmosphere occurs preferentially when the onset is later than normal. This process may be related to MJO activity. Nieto-Ferreira et al. (2011) addressed the possible role of western SAMS rainfall forcing in producing the shift in dynamical conditions that leads to monsoon onset in the SACZ region as well as the role of cold fronts in SAMS monsoon onset.

Table I shows the mean onset and end of the rainy season compiled from different studies. For, example, the mean onset determined by Liebmann and Marengo (2001) occurs during pentad 58 (13-17 October), two pentads before the onset given by LISAM and moisture flux criteria. 


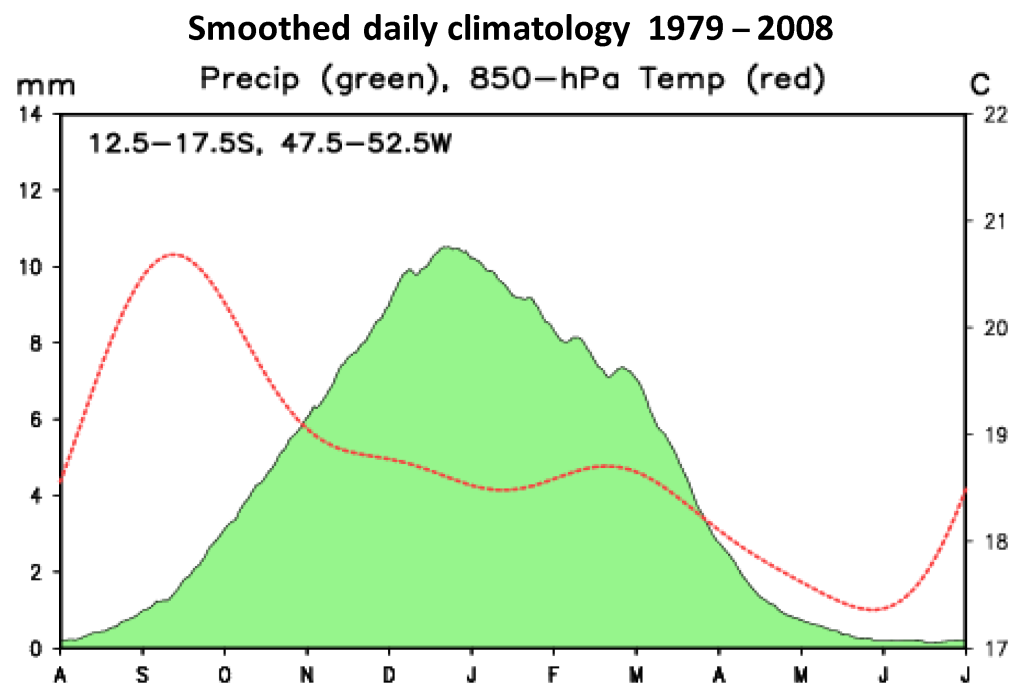

Figure 3. Mean (1979-2008) daily precipitation $(\mathrm{mm})$ for central Brazil $\left(12.5-17.5^{\circ} \mathrm{S}, 47.5-52.5^{\circ} \mathrm{W}\right.$; shaded in green), $850-\mathrm{hPa}$ temperature (degrees C; red curve). Source: V. Kousky. This figure is available in colour online at wileyonlinelibrary.com/journal/joc

Table I. Comparison between pentads of mean onset of the wet season in the SAMS. The following variables were used: PP: rainfall (LM: Liebmann and Marengo 2001; G1: Gan et al. 2004; NR: Nieto-Ferreira and Rickenbach, 2011); $850 \mathrm{ZWI}$ : 850 hPa zonal wind index; ZWSI: zonal wind shear index; UVI: $850 \mathrm{hPa}$ zonal and meridional wind index; MWSI: meridonal wind shear (G2: Gan et al. 2006); MF: zonal atmospheric moisture flux (RC: Raia and Cavalcanti 2008); and LISAM (SC: Silva and Carvalho 2007).

\begin{tabular}{cccccccccc}
\hline & $\begin{array}{c}\text { LISAM } \\
(\mathrm{SC})\end{array}$ & $\begin{array}{c}\text { PP } \\
(\mathrm{LM})\end{array}$ & $\begin{array}{c}\text { PP } \\
(\mathrm{G} 1)\end{array}$ & $\begin{array}{c}\text { PP } \\
(\mathrm{NR})\end{array}$ & $\begin{array}{c}850 Z \text { ZW } \\
(\mathrm{G} 2)\end{array}$ & $\begin{array}{c}\text { ZWSI } \\
(\mathrm{G} 2)\end{array}$ & $\begin{array}{c}\text { UVI } \\
(\mathrm{G} 2)\end{array}$ & $\begin{array}{c}\text { MWSI } \\
(\mathrm{G} 2)\end{array}$ & $\begin{array}{c}\text { MF } \\
(\mathrm{RC})\end{array}$ \\
\hline Onset & 60 & 58 & 58 & 61 & 58 & 58 & 62 & 62 & 60 \\
\hline
\end{tabular}

On the basis of LISAM, Figure 4 shows the mean onset of the SAMS for the period 1979-2007. The mean onset occurs in pentad 60 (23-27 October). The earliest onset was in pentad 58 (13-17 October during the summers of 1983-1984 and 2005-2006. The latest onset was detected in pentad 63 (7-11 November) during 1998-1999. The figure shows no apparent association between the occurrence of El Niño or La Niña and early or late onsets, in agreement with other studies on the SAMS and southern Amazon regions (Gan et al. 2004, and references cited therein). These years were classified according to both SST and the Southern Oscillation Index (SOI) following the NOAA classification (http://www.esrl.noaa.gov/psd/enso/)

Nieto-Ferreira and Richenbach (2011) detected a mix of early and late monsoon onset dates elsewhere in the SAMS domain during El Niño or La Niña, in agreement with Marengo et al. (2001). For the $5^{\circ} \mathrm{N}, 5^{\circ} \mathrm{S}$ portion of the SAMS, the aforementioned studies confirm that SAMS onset is influenced by ENSO, with late onset during El Niño episodes and a tendency for early monsoon onset during La Niña episodes. The early or late onsets are associated with the intensity of northwesterly/westward moisture flux to central/southeastern South America, as discussed in Raia and Cavalcanti (2008). In the late onset, the easterly flux is strong over the eastern coast of South America and last longer over the continent, inhibiting the northeasterly flow to the monsoon region. Strong northwesterly flux and weak easterly flux occur in the early onset.

Bombardi and Carvalho (2010) showed the influence of the South Atlantic Ocean SST on the SAMS variability. On inter-annual timescales, positive (negative) SST anomalies over the tropical South Atlantic are associated with late (early) onsets of the wet season over western and southeastern Brazil. A composite of wind nearby the onset date did not reveal a well defined precursor, suggesting the importance of local thermo-dynamical processes in providing necessary conditions for the onset $(\mathrm{Fu}$ et al. 1999).

\section{Diurnal, mesoscale, and synoptic variability}

The very wide and wet continental land mass over the equatorial region sustains a diurnal regime of convection that is quite distinct from that over drier land but still very well defined and controlled by land surface characteristics. The large magnitude of the Amazon and the central Brazil heat sources during the Southern Hemisphere summer drives significant responses in the vertical circulation of the adjoining regions.

Diurnal variability is dominant over mesoscale phenomena in the central Amazon, although westwardmoving squall lines initiated near the Atlantic coastline are important as well. The lack of observations with 


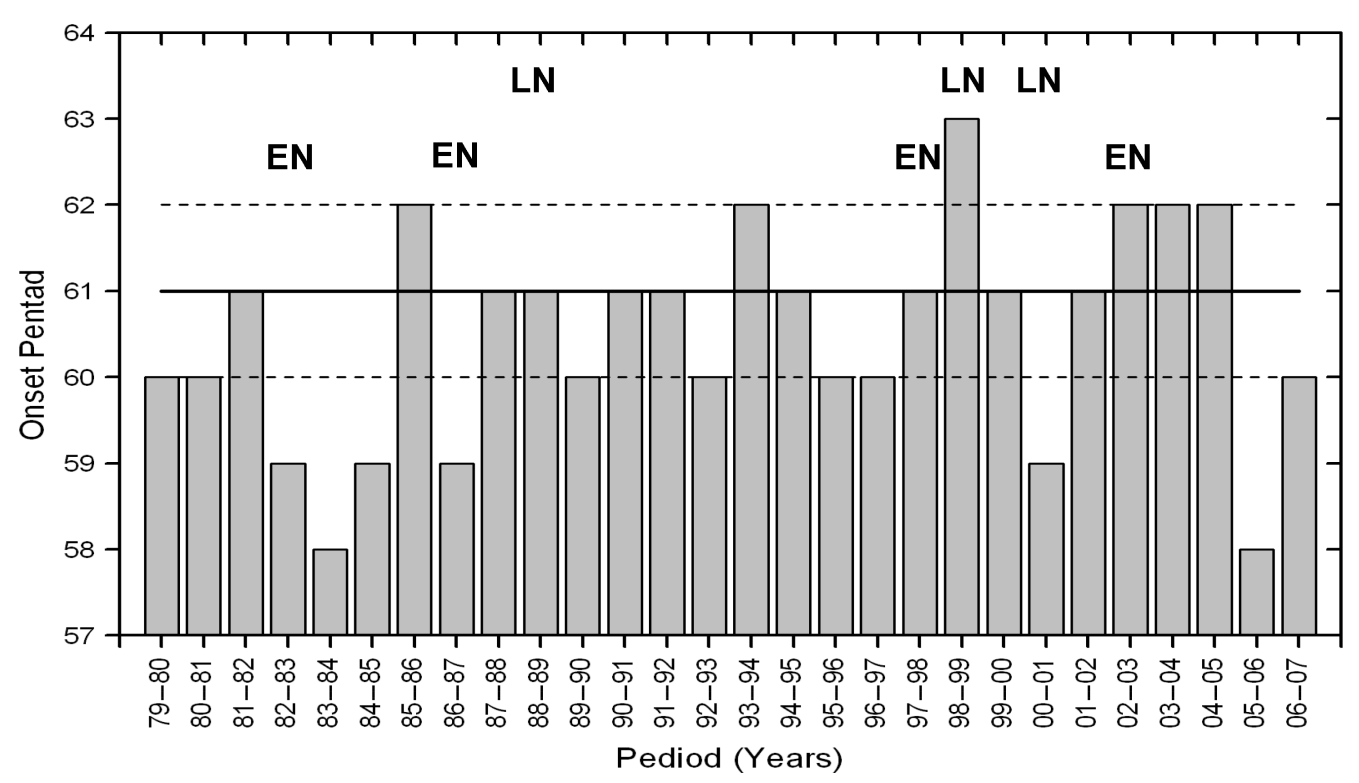

Figure 4. Mean onset of the SAMS based on LISAM, for the 1979-2007 period during austral summer. EN/LN shows the occurrence of El Niño/La Niña, following NOAA classification. Source: A. E. Silva.

adequate temporal and spatial resolution is an important limitation to the documentation of mesoscale circulations that may exhibit a diurnal oscillation.

The Large-Scale Atmosphere Biosphere Experiment in Amazonia (LBA) field campaign (LBA WET AMC; Silva Dias et al. 2002) has been helpful in providing insight into the diurnal cycle of rainfall and convection over the Amazon region. Rainfall episodes are characterised by regimes, the 'low-level easterly' and 'westerly' tropical winds in the context of the large-scale circulation. The westerly regime is related to an enhanced SACZ, but this condition generally corresponds to weaker precipitation in southeast South America and weaker SALLJ. The easterly regime is related to westward propagating systems (e.g. squall-lines), and would be associated with a suppressed SACZ and more precipitation in southeastern South America and stronger SALLJ. Diurnal variability of rainfall during the westerly surface wind regime shows a characteristic maximum in the late afternoon followed by a relatively weaker second maximum in the early evening (21:00 Local Standard Time LST). The easterly regime composite shows an early morning maximum followed by an even stronger maximum in the afternoon (Marengo et al. 2004a).

A nighttime peak of precipitation is observed in northern Argentina, northwestern South America, along the Atlantic ITCZ, and off the coast of southeastern Brazil along the SACZ (Berbery and Collini 2000). The nocturnal peak seems to be controlled by the very strong late afternoon and early evening peak of convective activity over the tropical sector of the continent and modified by the nocturnal peak in the SALLJ (Nicolini and Saulo 2006).

The SALLJEX field experiment (Vera et al. 2006b) has provided a unique opportunity to illustrate the characteristics of the diurnal cycle of the SALLJ. Using pibals and radisonde data at various SALLJEX sites, Nicolini et al.
(2004) showed that the winds exhibit oscillations consistent with PBL-related processes (i.e. the diurnal cycle of friction and differential heating over sloping terrain), but such oscillations do not show a regular cycle. A nighttime maximum of wind speeds has also been verified at those sites.

Large MCSs occur mostly at night in all the regions studied (Laing and Fritsch 2000; Nesbitt and Zipser 2003), and are consistent with a nocturnal maximum of inflow of warm moist air from low-level jets (Salio et al. 2007; Durkee and Mote 2009, and references cited therein). TRMM data show that the MCS nocturnal/early morning maximum (0130 UTC-1030 UTC (Figure 5), as derived from TRMM data), are often co-located with the exit region of strong SALLJ. Abrupt changes in the diurnal cycle of convection also occur in the westeast direction and at relatively small distances. Durkee and Mote (2009) used infrared images of GOES- 8 and 12 infrared images to show that the MCCs reached maximum size between $20: 45$ and $11: 45$ UTC.

An example of significant changes in the diurnal cycle of convection over the Altiplano was shown by Falvey and Garreaud (2004). A distinctive climatic feature of the Altiplano is the vigourous afternoon convection between December and March, which contributes more than $90 \%$ of the annual precipitation. An analysis from GOES data during the SALLJEX period suggested that this maximum convective activity may not be related to the same synoptic regime at different areas over the Altiplano. The behaviour documented in a large area, including the western and southern Altiplano (Garreaud 1999), seems to be different than the behaviour in the convection regime that appears to operate in the northeastern Altiplano (Lake Titicaca basin and mountains to the north).

In a more recent study, Misra (2009) showed that ENSO influence on precipitation over the equatorial Amazon is manifested to a large degree as variations 

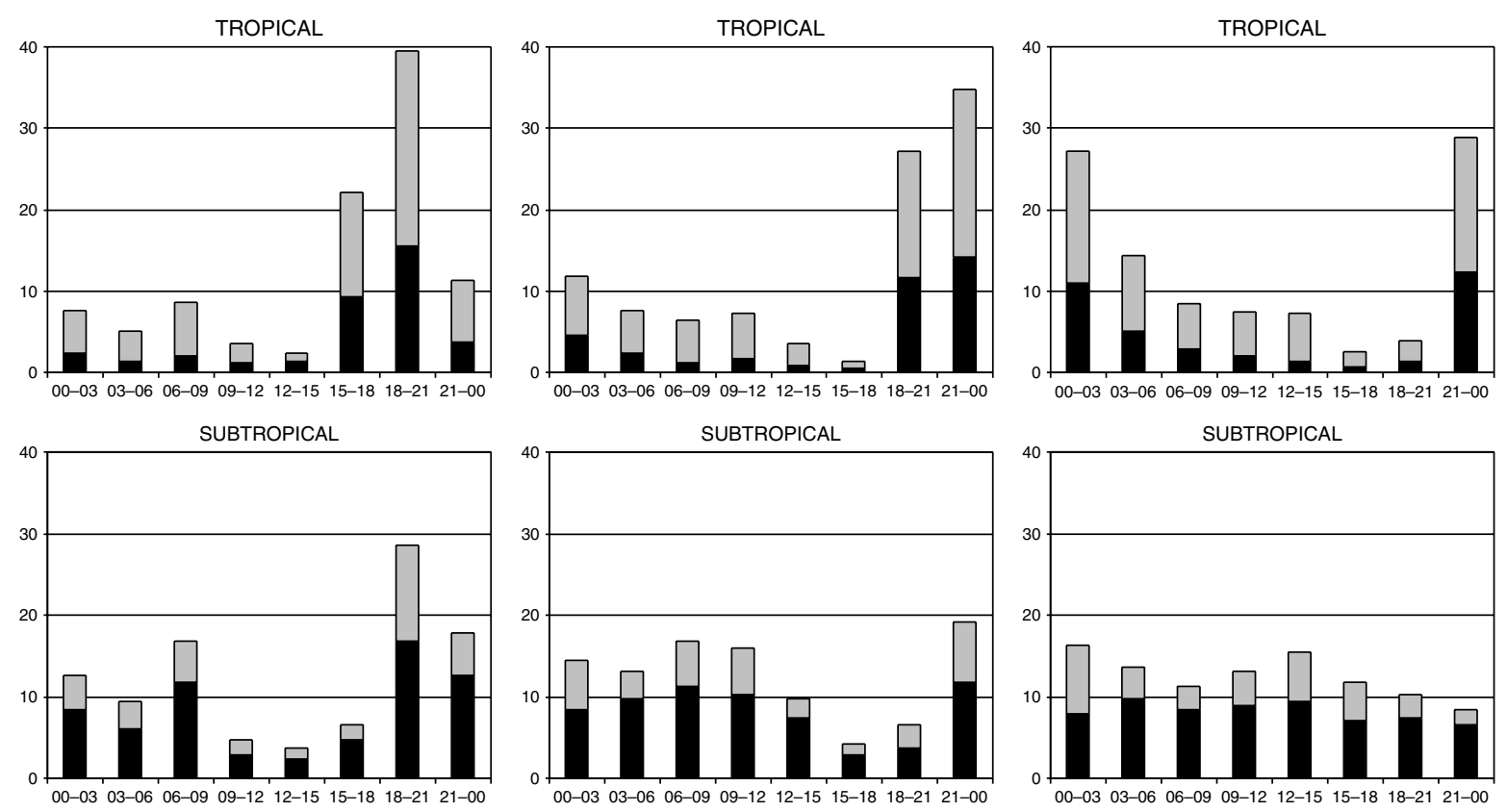

Figure 5. Frequency distributions in percent of MCSs for SALLJ (dark grey) and NOSALLJ (light grey). Samples of (left) initiation, (middle) maximum extent, and (right) dissipation time in UTC. (From Salio et al. 2007).

of the diurnal precipitation range at inter-annual time scales (Figure 6). Misra (2009) attributed this feature to inter-annual variability of the diurnal variation of the moisture flux convergence. The land feedback is found to play a more passive role in maintaining the inter-annual precipitation anomalies over the equatorial Amazon.

The aforementioned issues clearly indicate the relevance of the diurnal cycle to a better understanding of the SAMS. Such interactions need to be observed, and for such, there is a need for sustained monitoring and assessment of the diurnal cycle, which will require high spatial and temporal resolution of observing platforms.

\section{Intra-seasonal variability}

Intra-seasonal variability (ISV), defined here as variability on roughly 10-90 days, is relatively large over eastern South America (Carvalho et al. 2002; Grimm et al. 2005) and northeast Brazil (Jones and Carvalho 2002; Souza and Ambrizzi 2006). Active and break periods of the monsoon occur on intra-seasonal time scales (Jones and Carvalho 2002), and affect convection on a broad range of spatiotemporal scales (Carvalho et al. 2002; Ciffeli et al. 2002). Sub-seasonal variations in SAMS may result from the propagation of midlatitude disturbances into the region and also from the amplification of wave activity in the Northern Hemisphere with subsequent enhancement of northwesterly cross-equatorial moisture transport over tropical continental South America (Carvalho et al. 2010).

The Madden-Julian Oscillation (MJO) is presently the best understood source of intra-seasonal variability affecting South America. Further, it is the only source of intra-seasonal variability for which potential predictability has been demonstrated (Jones et al. 2004). The MJO influence seems to be related to a combination of its forcing tropical circulation changes and from its effect on midlatitude Rossby wave trains that propagate into South America. Teleconnection studies have indicated that 30-60 day variability over the SACZ region can be forced by Rossby wave propagation linked to MJO events in the Pacific Ocean, and directly along the Equator as well (Grimm and Ambrizzi 2009).

Cunningham and Cavalcanti (2006) identified two modes of intra-seasonal variability associated with the SACZ position: a tropical zonal mode, associated with the MJO when the SACZ is displaced northward of its climatological position, and a tropical-extra-tropical mode, associated with the Pacific South America (PSA) teleconnection when the SACZ is displaced southward or in the climatological position. Carvalho et al. (2004) quantified that an intense SACZ most often persists during the end of the MJO life cycle, which is consistent with the anomalies described by Nogués-Paegle and Mo (1997). Liebmann et al. (2004) obtained similar results and argued that the MJO influenced the phase of the midlatitude synoptic disturbances that affect the SACZ.

\section{Inter-annual and interdecadal variability}

Most of the explained inter-annual variability of monsoon system precipitation comes from ENSO (Paegle and Mo 2002; Grimm 2010 and references cited therein). During its warm (cold) phase, precipitation is below (above) average in northern South America during the summer wet season and is enhanced (reduced) in SESA, as shown in Figure 9, right panel, due to a combination of Walker and Hadley circulation anomalies, and anomalous Rossby wave activity (Figures 9(a), (b)) (Grimm 2003, 

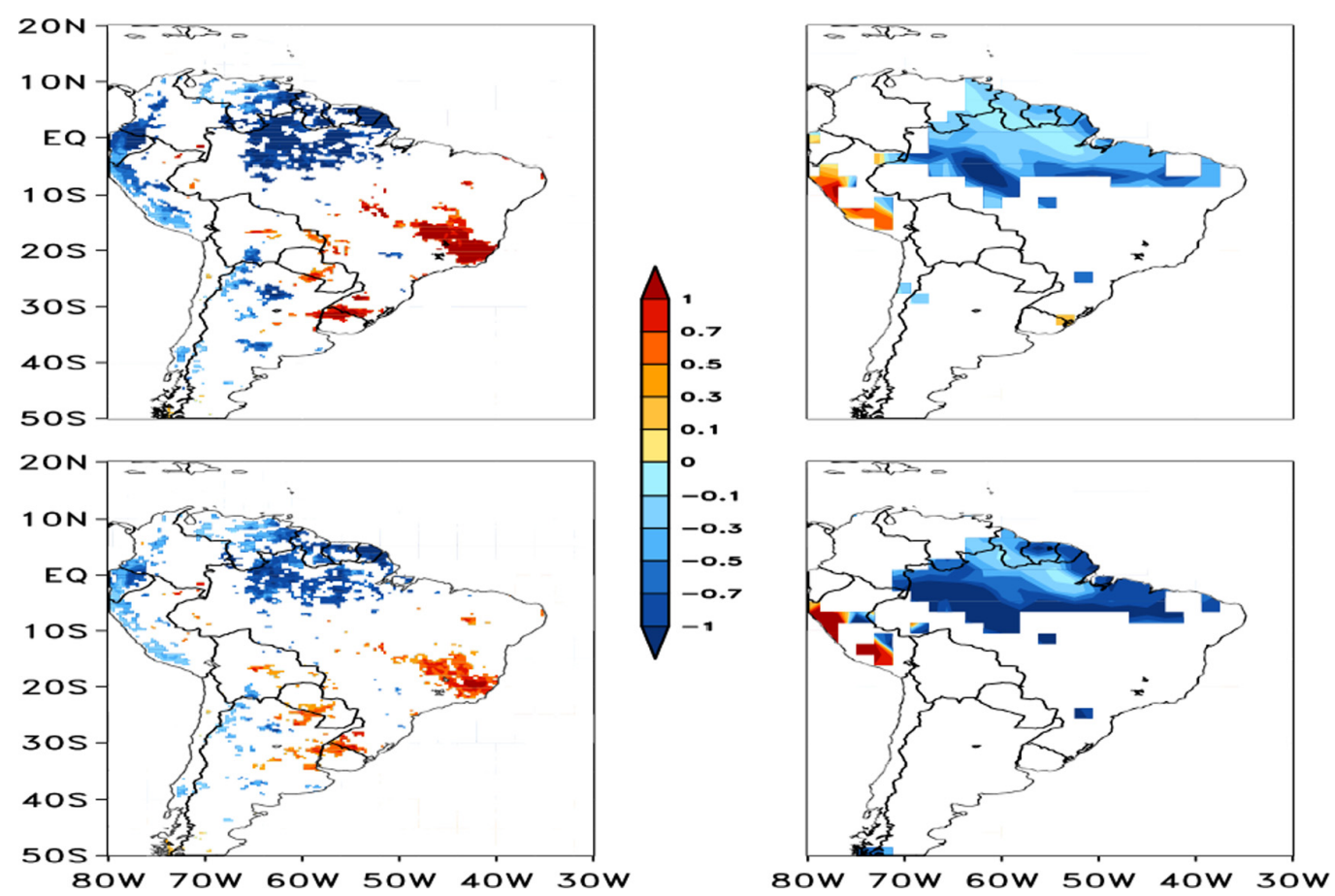

Figure 6. The contemporaneous regression of the December-January-February seasonal mean: a) precipitation from TRMM on the normalised Niño3 SST index from HADISST; and b) precipitation from the coupled model simulation on the normalised Niño3 SST index from the same coupled model simulation. Similarly, the contemporaneous regression of the December-January-February seasonal mean: c) diurnal precipitation range from TRRM on the normalised Niño3 SST index from HADISST; and d) diurnal precipitation range from the coupled model simulation on the normalised Niño3 SST index from the same coupled model simulation. This figure is available in colour online at wileyonlinelibrary.com/journal/joc

2004; Vera et al., 2004; Grimm and Ambrizzi 2009; and references cited therein).

Except for these long established mechanisms, however, little has been known until recently about the variability of those impacts throughout the monsoon season. Grimm $(2003,2004)$ found in central-east South America consistent wet (dry) anomalies in January $(+)$ of El Niño (La Niña), while in November (0) the anomalies tend to be opposite (Figures 9(c), (d)). Furthermore, the ENSO-related modes in spring and summer (Figure 9, left and right panels) are associated with fairly similar SST anomalies, but present opposite rainfall anomalies in this region, whereas the anomalies in SESA are shifted southwestward in summer with respect to spring (Grimm and Zilli 2009; Grimm 2010). Ropelewski and Bell (2008) showed that in this region there is a robust shift in histograms of daily gridded precipitation toward an increase in larger events during the summer season of an El Niño year (DJF), whereas in spring (SON) there are fewer large events. The tendency for precipitation anomalies to reverse between spring and summer, especially in central-eastern South America, suggests that regional surface-atmosphere interactions compete with remote influences during at least part of the season (Grimm et al. 2007a). In spring of an El Niño year, remote influences dominate, since this is the most favourable season for teleconnections between SESA and the tropical Pacific Ocean (Grimm 2003; Cazes-Boezio et al. 2003) while in summer, land surface processes prevail.
The reversal of anomalies from spring to summer in central-east South America can also occur in non-El Niño years, provided that spring anomalies are large. The first modes of continental precipitation in spring and summer (Figure 8) are positively correlated and associated with an anomalous vortex over southeast Brazil that conveys moisture from the Atlantic, northwestern South America and Amazon Basin into central-east South America, decreasing its transport into SESA (if it is cyclonic), or increasing its transport into SESA and northwestern South America (if it is anticyclonic) (Grimm and Zilli 2009; Grimm 2010). Koster (2004) showed that summer precipitation over monsoon regions is sensitive to soil moisture variation. However, in central-east South America, the relationship between summer precipitation and the soil moisture anomalies resulting from spring precipitation seems to be more indirect than the positive feedback between soil moisture and precipitation through evaporation anomalies.

The hypothesis proposed to explain the reversal of precipitation patterns between spring and summer is that the precipitation anomalies remotely forced in the spring produce soil moisture and near-surface temperature anomalies, which alter the surface pressure and wind divergence. This, in conjunction with the effect of the mountains in southeast Brazil, reverses the anomalous vortex over southeast Brazil and the rainfall anomalies in summer. The SST anomalies off the southeast coast of Brazil in spring enhance this effect (Grimm et al. 2007a). 
(a)

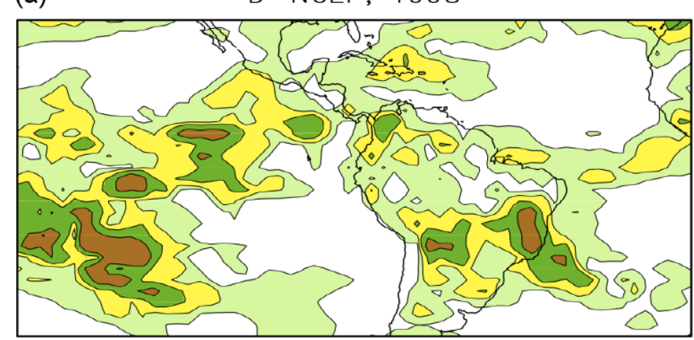

(b)

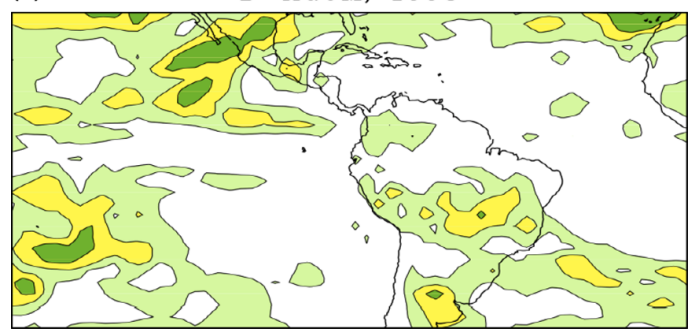

(c)

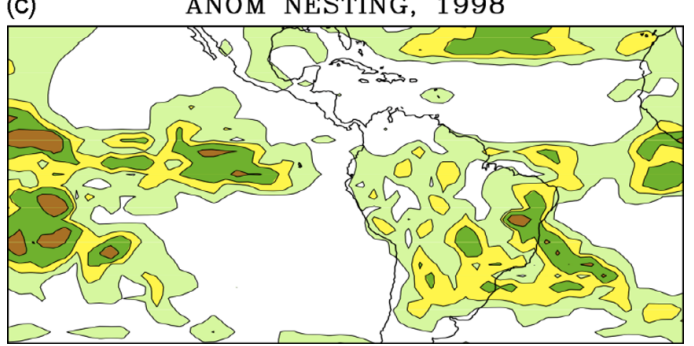

(d)

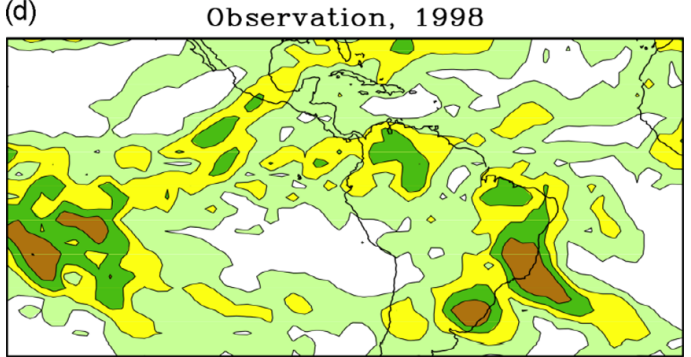

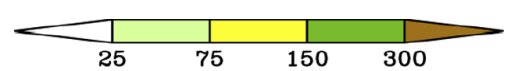

Figure 7. 30-40 days filtered OLR variance for January-February-March 1998 from: a) RSM forced with NCEP reanalysis (D-NCEP); b) RSM forced with COLA AGCM (D-AGCM); c) RSM anomaly nested into COLA AGCM (ANOM Nesting); and d) NOAA OLR. This figure is available in colour online at wileyonlinelibrary.com/journal/joc

Besides those associated with ENSO, other connections between precipitation and SST anomalies have been described, but their causes and effects are difficult to identify. For instance, enhanced (suppressed) precipitation in the SACZ has been related to colder (warmer) SSTs in the southwestern sub-tropical Atlantic near the SACZ (Robertson and Mechoso 2000; Doyle and Barros 2002), indicating atmospheric control over the ocean in this region. On the other hand, in connection with the tendency toward spring-summer reversal of precipitation anomalies described above, Grimm (2003) showed that January rainfall in central-east Brazil is positively correlated with previous November SSTs in the oceanic SACZ, off the southeast coast of Brazil, and negatively correlated with January SST in the same region, suggesting that warmer SSTs in November help trigger the regional circulation anomalies that lead to enhanced precipitation in January. This hypothesis is consistent with the results from the observational study of Almeida et al. (2007) and with some modelling studies (Robertson et al. 2003; Chaves and Nobre 2004; Drumond and Ambrizzi 2005; Grimm et al. 2007a; Misra 2008a), since there are possible feedback mechanisms between SST and the atmosphere in the SACZ.

The importance of this two-way interaction between atmosphere and ocean, which seems to be more significant in the Atlantic than in the Pacific Ocean, is stressed by the analysis of integrations of atmospheric general circulation models (AGCMs) with coupled models (Siqueira and Nobre 2006; Misra 2008a, b). Misra (2008a) contrasted the SAMS response in forced AGCM integrations (wherein observed SST is prescribed) with simulations from the same AGCM, but coupled to an ocean general circulation model (OGCM), and found that the SAMS inter-annual variability of precipitation is best modelled in the latter. The atmosphere forcing of the SST anomalies over the oceanic portion of the SACZ, which is an important feature of the SAMS, is not captured in the forced AGCM runs, implying atmospheric feedback onto SST.

The influence of the Atlantic SST anomalies on the inter-annual variability of the SAMS has been studied, although not as extensively as the influence of the Pacific SST anomalies. Besides the local influence in the SACZ region, the Atlantic SST anomalies are also important to the variability of the southern Amazon Basin. For instance, the 2005 drought of southern Amazonia was not related to ENSO but to the tropical Atlantic variability (Marengo et al. 2008; Cox et al. 2008; Zeng et al. 2008). Atlantic variability also plays a role in inter-annual variations of extreme precipitation over southeastern Brazil (Muza et al. 2009).

Significant ENSO-related changes in the frequency of extreme rainfall events are much more extensive than changes in monthly rainfall. The grey areas in Figure 9 show the significant monthly anomalies, and the coloured areas in Figure 10 show the significant differences in the frequency of extreme events. ENSO influence seems to be stronger in the more intense daily precipitation categories (Grimm and Tedeschi 2009). This is an important aspect, since the most dramatic consequences of climate variability are related to its influence on extreme events.

Some case studies have shown a link between El Niño and SALLJ. Berbery and Barros (2002) suggested that during the austral summers of three of the largest El Niño events from 1980 to 2000, the large-scale patterns showed an increased southward component of moisture flux over 

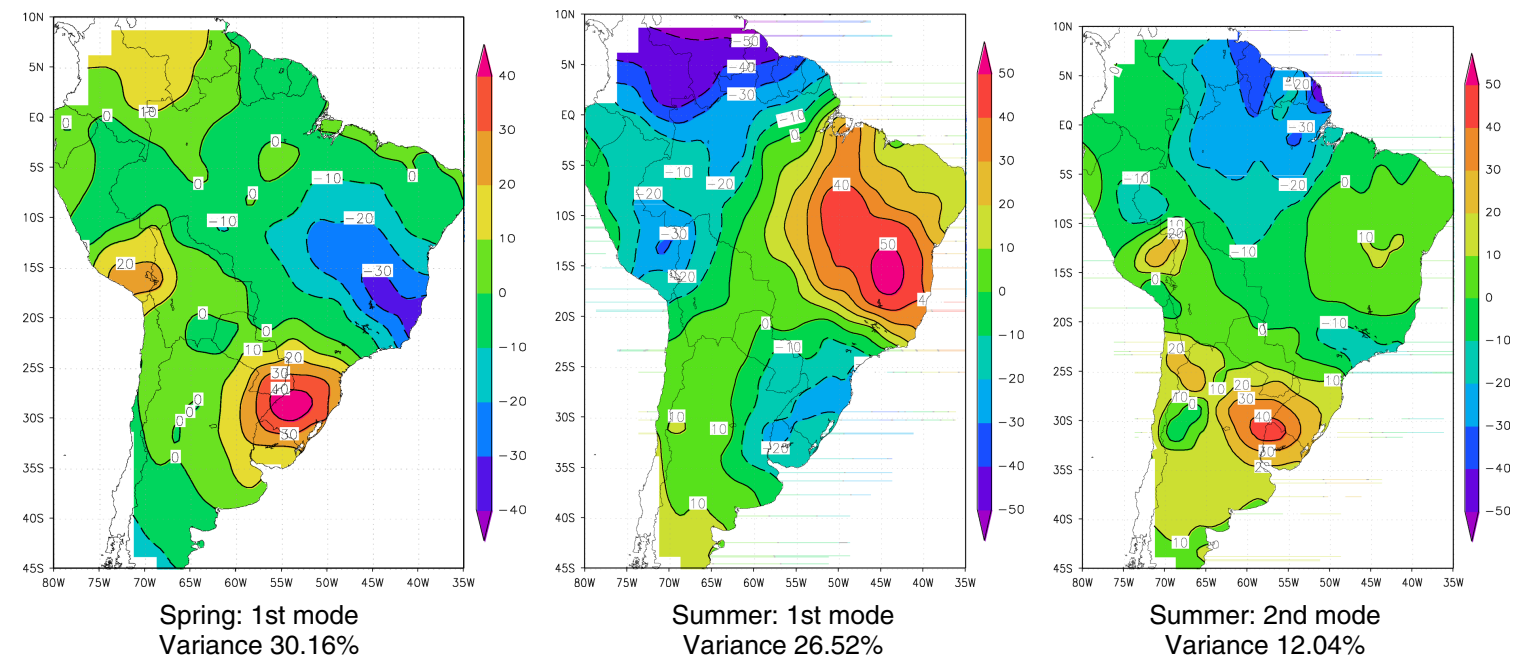

Figure 8. Spatial pattern of the first variability mode of spring precipitation (left panel), and the first and second modes of summer (centre and right panels) (from Grimm 2010). This figure is available in colour online at wileyonlinelibrary.com/journal/joc

La Plata Basin. Similarly, Misra et al. (2002) showed in their regional modelling studies that the SALLJ is stronger during warm ENSO events than during cold events.

Basing on limited upper-air observations, NietoFerreira et al. (2003) and Marengo et al. (2004b) found that the SALLJ in JFM was much stronger and transported more moisture poleward during El Niño in 1998 than during La Niña in 1999. Silva and Ambrizzi (2006) and Silva et al. (2009) analysed cases of the SALLJ during El Niño and La Niña episodes and concluded that, during El Niño years, the increase in the SALLJ is linked to the intensification of the northeasterly trade winds over the northern continent, there, later, are channelled by the Andes into the La Plata Basin region. Anticyclonic anomalies over central South America and cyclonic anomalies southwest of South America (Figure 9) result in an enhancement of the SALLJ during El Niño episodes. On the other hand, enhanced southward moisture influx from tropical to sub-tropical regions has been associated with positive SST anomalies over the southwestern tropical Atlantic Ocean by Doyle and Barros (2002).

The impact of ENSO-related variability on the frequency of extreme precipitation events also changes by month. Figure 10 shows the impact for November (0) and January (+) (Grimm and Tedeschi 2009). One of the most affected regions is La Plata Basin, more specifically SESA, especially in November (0), due to the enhancement of meridional moisture flux through the SALLJ. In January (+), the SESA region most affected shifts southwestward. However, there are also areas in centraleast South America, including the SACZ region, with enhanced frequencies of extreme events. These trends are in agreement with studies by Liebmann et al. (2001) and Carvalho et al. (2002, 2004).

Land-surface processes also have impacts on interannual variations in SAMS. Through sensitivity modelling experiments, Collini et al. (2008) explored possible feedbacks between soil moisture and precipitation during early stages of the monsoon, when the surface is not saturated. They identified two mechanisms by which soil moisture has a positive feedback on precipitation. The two mechanisms - reduced convective instability and reduced moisture flux convergence - act concurrently to diminish the core monsoon precipitation. Similar results were obtained in Saulo et al. (2010) for a particular case study, where they show that reduced soil moisture also causes a southward displacement of the rain field. Analyses of South America precipitation and river stream flow have also shown modes of interdecadal variability in connection with regional or global non-ENSO SST and atmospheric variations, such as the PDO and NAO (Robertson and Mechoso 2000; Zhou and Lau 2001; Paegle and Mo 2002). The activity of the Southern Annular Mode (SAM), mostly associated with intensification and weakening of the Southern Hemisphere westerlies, has been related to inter-annual changes of seasonal precipitation over southeastern South America (Silvestri and Vera 2003). Interdecadal changes of such influence onto South American climate have been recently identified (Silvestri and Vera 2009).

Chiessi et al. (2009) investigated the impact of the Atlantic Multidecadal Oscillation AMO on the SAMS using 4500-year-long records of the La Plata River Drainage Basin, estimated by stable oxygen composition of shallow-dwelling planktic foraminifera (controlled by the extension of the river plume). The results suggest a periodic oscillation of about 64 years in both the extension of the river plume and the source of the terrigenous sediments. The results also suggest that this observed oscillation reflects variability in the SAMS activity associated with the AMO.

The interdecadal variability of annual precipitation totals shows a change of phase in the mid-1970s, corresponding to a change of phase in the NAO and PDO. Garcia and Kayano (2008) found that the Hadley and monsoon circulations show small differences between the 


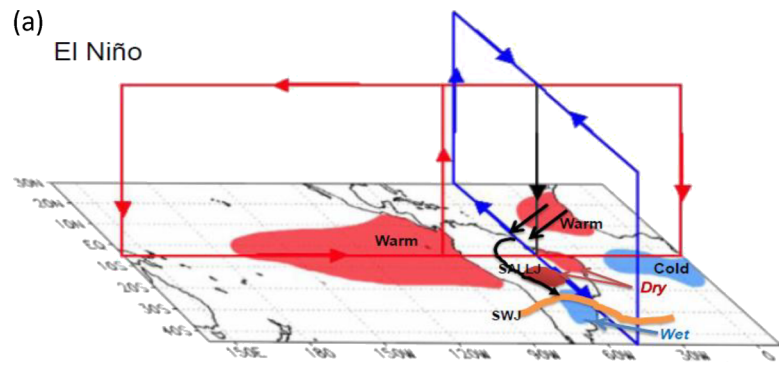

(c)

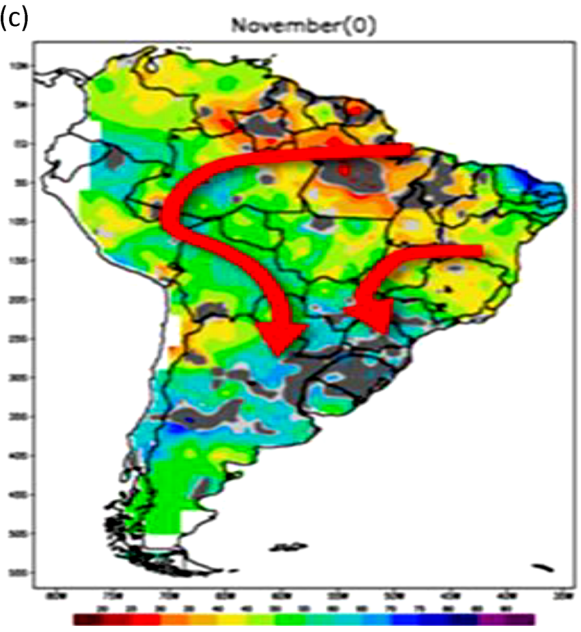

(b)

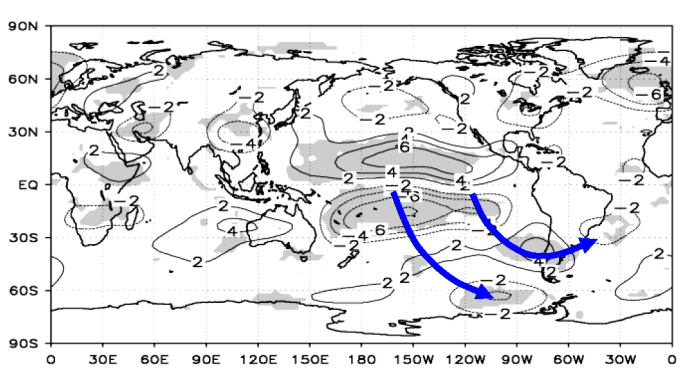

(d)

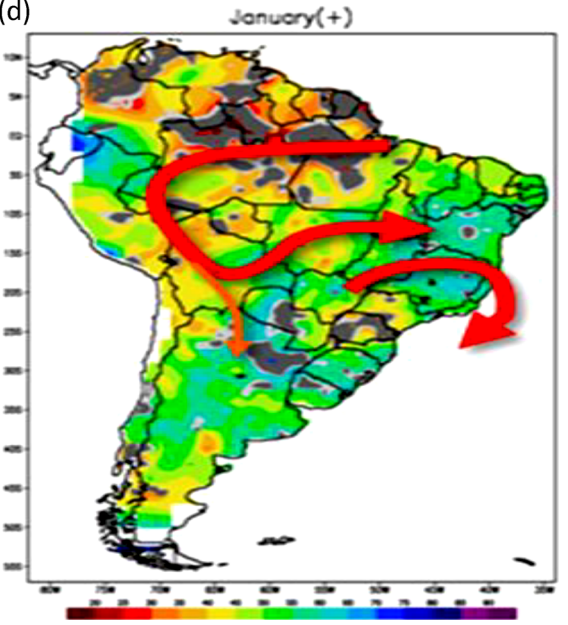

Figure 9. (a) Anomalies of the Walker and Hadley circulation (from Ambrizzi et al. 2004); and (b) stream-function anomalies at 200-hPa in November of El Niño years (from Grimm and Ambrizzi 2009). Expected precipitation percentiles for El Niño events in (c) November (0), and (d) January $(+)$, with schematic moisture flux or low-level circulation anomalies (extended from Grimm 2003). This figure is available in colour online at wileyonlinelibrary.com/journal/joc

periods 1958-1976 and 1977-1995, whereas the Walker circulation shows weaker action centres during the second period, centred farther west in the western Pacific.

Carvalho et al. (2010) have identified significant changes in the mean circulation and moisture transport patterns in the SAMS region in the early 1970s that resulted in early onsets before and late demises after 1972. They also identified increases in the vertically integrated moisture flux over South America after 1971-1972. Even the spatial patterns of intra-seasonal variability of rainfall undergo interdecadal modulation (Ferraz and Grimm 2004), as does the ENSO impact on precipitation (Grimm and Ferraz 2002) and the frequency of extreme precipitation events (Pscheidt and Grimm 2009).

Studies conducted with limited data (Marengo 2004, Satyamurty et al. 2009) have identified interdecadal rainfall variations in the Amazon region, with 'breaks' in the mid-1940s and 1970s approximately when the Pacific Decadal Oscillation PDO changed patterns. After 1970, Li et al. (2008) observed a significant negative trend in the standardised precipitation index over southern Amazonia for the period 1970-1999.

\section{Long-term variability and climate change}

Few studies have focused on changes in the large-scale circulation and in the regional monsoon circulations in the context of a global warming scenario. The American monsoon regions are vulnerable to long-term climate variability and change and especially to extreme climate events such as intense droughts and floods (Kunkel et al. 2008; Soares and Marengo 2008; Marengo et al. 2009b; Rusticucci et al. 2009).

\subsection{Observed changes}

Chase et al. (2003) and Wang and Ding (2006) examined changes in several indices of four major tropical monsoonal circulations outside the SAMS for the period 1950-2003 and found a consistent picture of significantly diminished monsoonal circulation. However, identification of a comprehensive pattern of long-term trend precipitation and extremes in the monsoon region is nearly impossible because of a lack of stations with continuous and homogeneous data.

Observed trends in rainfall extremes have been identified in the SAMS region, where data coverage is better (Marengo et al., 2009c; Rusticucci et al. 2009; Alexander et al. 2006; Haylock et al. 2006, and references cited therein). They suggested a pattern of increasing frequency and intensity of heavy rainfall events in the last 50 or 60 years. Penalba and Robledo (2010) observed increases in the annual frequencies in spatially coherent areas over the La Plata Basin for both heavy ( $>75$ th) and all $(>0.1 \mathrm{~mm})$ precipitation events during summer, autumn 

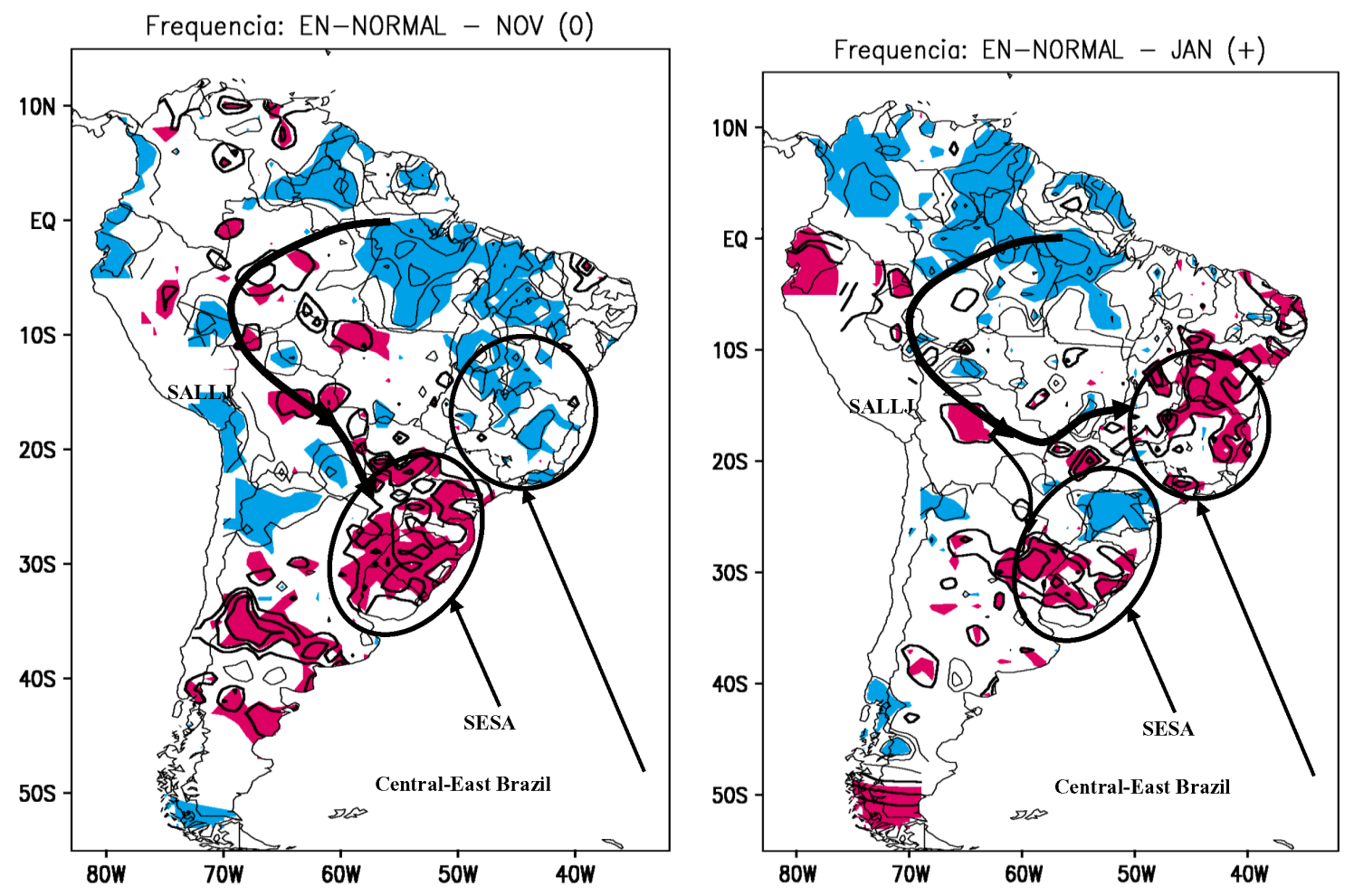

Figure 10. Differences between numbers of extreme rainfall events in El Niño years and neutral years in November (left panel) and January (right panel). Extreme events are defined as three-day running mean precipitation above the 90th percentile. Contour interval is 1 event. Positive (negative) differences significant over the $90 \%$ confidence level are represented by dark (light) gray shades (in the online version positive differences are represented by red colour and negative differences by blue colour). Schematic moisture flux is indicated (adapted from Grimm and Tedeschi 2009). This figure is available in colour online at wileyonlinelibrary.com/journal/joc

and spring for the period 1950-2000. Winter is the exception, with negative trends, some of which are significant in the lower and middle Uruguay and Paraná Rivers.

\subsection{Projected changes}

As global warming will lead to faster warming over land than oceans, the continental-scale land-sea thermal contrast will become larger in summer and smaller in winter. As a consequence, the monsoon could become stronger in summer and weaker in winter. However, model projections show a weakening of these tropical monsoon circulations by the late 21 st Century compared to the late 20th Century (Tanaka et al. 2005).

In the Amazon, temperature rise is expected to lead to rainfall reduction and dryness, with greater loss of soil moisture, causing potential alterations of the Amazonian biome. Vegetation and land cover are thought to play a significant role in modulating monsoon variability through changes in land surface fluxes and moisture recycling to the atmosphere. Changes in regional monsoons are highly influenced by changes in the states of dominant patterns of climate variability such as ENSO and PDO. However, it is not always clear how those modes may have changed in response to external forcing. Although PDO variations could possibly be explained by natural climate variability, yet it is less known whether its variability is also forced by anthropogenic human change (e.g. land use change and deforestation). Few attribution studies have linked the PDO variability to the increase in concentration of greenhouse gases (Shiogama et al. 2005), but simulations suggest that the observed variability includes an unusually large trend relative to the natural variation, and that anthropogenic forcing may be causing this trend.

Current climate models are able to reproduce the main features of the seasonal cycle of precipitation during the 20th Century. However, they fail in reproducing the observed amounts of mean seasonal precipitation over both tropical and sub-tropical regions of South America (Vera et al. 2006c; Boulanger et al. 2007; Cavalcanti et al. 2006; Bombardi and Carvalho 2009).

Climate change projections for the A1B scenario in South America show a substantial agreement among IPCC AR4 models in precipitation changes for the period 2070-2099 relative to the period 1970-1999, mainly characterised by an increase of summer precipitation over the northern Andes and SESA, with mixed results over the Amazon-SACZ (Vera et al. 2006c). Seth et al. (2010) analysing a multi-model IPCC AR4 ensemble suggest reduced precipitation along the continental $\mathrm{SACZ}$ region during austral spring for the A2 scenario, accompanied by a southward shift of the maximum precipitation in the convergence zone. This is mainly due to a strengthened SALLJ and South Atlantic High by the late 21st Century, which enhances moisture transport to the Southeast. This change is consistent with the alterations on the behaviour of the SALLJ for the period 2071-2100 identified by Soares and Marengo (2008) using the HadRM3P. 
Grimm and Natori (2006) analysed the summer monsoon rainy season in South America and its relationship to SST as projected by the ECHAM5-OM model for the A2 scenario, concluding that the relationship between ENSO events and precipitation variability in SESA weakens especially in spring. However, Vera and Silvestri (2009), analysing the output of seven models, found that models exhibit considerable dispersion in their response of both Southern Hemisphere circulation and South America precipitation to ENSO changes.

Moreover, models do not agree in the sign of the trend of large-scale changes in the monsoon circulation or rainfall, and models of finer resolution do not provide better representations of tropical monsoon circulation trend (Kim et al. 2008). Although most IPCC AR4 models reproduce the main modes of variability of the Atlantic they do not succeed in representing the correct relationships with SAMS's variability (Bombardi and Carvalho 2010).

Downscaling experiments on climate change scenarios in South America, based on both SRES A2 and B2 emission scenarios for the end of the 21st Century, suggest a reduction in Amazonia rainfall and a small increase in SESA rainfall, as well as an increase in dry spells and intense rainfall events in the SAMS/SESA region (Marengo et al. 2009a, b; Nuñez et al. 2008; Soares and Marengo 2008). The projected increase in total and heavy rainfall in SESA, particularly after 2050, is consistent with a projected increase in the frequency of SALLJ events, and with an increase in dry spells. This suggests that future rainfall would be more concentrated on short periods of time followed by longer dry spells, which is in agreement with the findings of Tebaldi et al. (2006). All these projections suggest potential changes in rainfall extremes in the SESA and SAMS regions.

\section{Land-surface processes and the role of aerosols from biomass burning}

The historical influence of land use and land use changes on monsoons has been difficult to quantify, due to both the poor documentation of land use and difficulties in simulating monsoon at fine scales. Moreover, there are still large uncertainties and a strong model dependency in the representation of the relevant land surface processes and resulting interactions that still need to be improved in climate models (Pitman et al., 2009).

Broad regions in southeastern South America and southern Amazonia have been experiencing significant changes in land surface characteristics over the last 30 years due to intensive deforestation and land-use changes associated with agriculture expansion. Model experiments performed since the 1990s have suggested that land surface processes and land use changes in the form of deforestation could in some instances significantly impact climate in the Amazon and SAMS regions (Sampaio et al. 2007 and referenced cited within). More recent experiments by Nobre et al. (2009) suggested significant rainfall reductions (up to 60\%) due to deforestation in Amazonia, and significant remote atmospheric responses to Amazon deforestation scenarios, suggesting enhanced El Niño Southern Oscillation (ENSO) activity over the Pacific, and a positive feedback contributing to the extra rainfall reduction over the Amazon on the coupled simulations.

Some model projections (Betts et al. 2004; Cox et al. 2004; Salazar et al. 2007; Sampaio et al. 2007; and Sitch et al. 2008) exhibit over the next several decades a risk of an abrupt and irreversible replacement of Amazon forests by savanna-like vegetation, with possible largescale impacts on climate, biodiversity, and people in the region. This process is referred to as the 'die-back' of the Amazon, and is simulated by few climate models. After reaching a 'tipping point' in climate $\left(\mathrm{CO}_{2}\right.$ concentration, air temperature) the forest stops behaving as a carbon sink and becomes a carbon source. After that, the forest enters a state of collapse and is then replaced by savanna-type vegetation in a process that has been referred to as the 'savannisation' of the Amazon region. The resilience of the forest to the combined pressures of deforestation and climate change is therefore of great concern, especially since some major climate models predict a severe drying of Amazonia in the 21st Century (Betts et al. 2008; Malhi et al. 2008, 2009; Nobre and Borma 2009). The likelihood of this die-back scenario occurring, however, is still an open issue.

With regard to changes in the hydrology of large rivers in SAMS due to change in vegetation, Coe et al. (2009) observed a discharge increase between 5 and $7.5 \%$ at the Madeira, Tapajós, and Xingu Rivers based on numerical models. However, observations do not show those projected trends, mainly because of the non-linear nature of the aggregation of hydrological processes across spatial scales, particularly in heterogeneous landscapes. One of the distinctive features between the hydrological behaviour at small and large scales is related to vegetation atmospheric feedbacks. Although feedback mechanisms are present in all scales, the atmosphere influence is more significant at large scales.

Increased aerosol loading in the atmosphere may also have strong impacts on monsoon evolution (Menon et al. 2002; Liu et al. 2005). Monitoring of biomass burning over tropical South America shows that smoke particles from fires in Southern Amazonia-SAMS region are transported southward by the mean flow and can affect areas of southeastern South America. Ensemble simulations from regional climate models forced by aerosol radiative forcing suggest that biomass-burning aerosols can work against the seasonal monsoon circulation transition, thus reinforcing the dry season rainfall pattern for southern Amazonia. Strong absorption of smoke aerosols warms and stabilises the lower troposphere within the smoke centre in southern Amazonia (Freitas et al. 2004, 2009). However, the uncertain role of aerosols in general, and carbon aerosols in particular (Liu et al. 2005), complicates the nature of future projections of monsoon precipitation, particularly in Asia and the SAMS. The precipitation change due to the direct radiative impact 
of biomass burning is generally negative (i.e. there is a decrease in precipitation). However, recent modelling experiences suggest a positive impact that has been associated with the dynamic impact of the low-level horizontal pressure gradients produced by the aerosol plumes (Vendrasco et al. 2009).

\section{Modelling, prediction and predictability}

The most prominent climatological signatures of the SAMS are simulations reasonably well simulated by AGCMs. The models simulation of the Bolivian High, Atlantic trough, South Atlantic Convergence Zone (SACZ), sub-tropical Atlantic high, and the ITCZ are all located near their observed positions, and with the correct magnitude. These features are also evident in regional simulations (Seth et al. 2006; Vera et al. 2006a).

Although the large-scale features of the SAMS region are reasonably well simulated, precipitation tends to be underestimated in the Amazon region (Vera and Silvestri 2009 and references cited therein). In addition, some models overestimate precipitation in the southern part of the SACZ. Other systematic errors over South America include excessive precipitation over the Andes Mountains in summer and a deficit of precipitation over southern/southeastern South America, errors that are related to model limitations in representing the right amplitude of the seasonal cycle (Cavalcanti et al. 2002a). Some improvement in the representation of precipitation and circulation patterns when a downscaling approach is adopted has been reported by da Rocha et al. (2009) and Marengo et al. (2009a).

The SAMS's onset and demise identified in observational studies are reasonably reproduced in a climate simulation with the CPTEC/COLA AGCM, using the criterion based on atmospheric humidity flux, as in Raia and Cavalcanti (2008). The model exhibits the main atmospheric characteristics associated with the SAMS life cycle. However, the intensity and location of some atmospheric features, which are important to the transition phases of the SAMS, are not properly represented by the model.

Intra-seasonal oscillations have been analysed in atmospheric and coupled ocean-atmosphere models. Jones and Schemm (2000) analysed 5-year results of 50-day integrations from a medium-range forecast model over South America and found more skill over SACZ during periods of strong convective activity associated with MJO than during periods of weak activity. The model skill was low when the convection was associated with 10-30-day band variation. This result shows the increase of extended range predictability when the intra-seasonal variability is considered.

The influence of ISV has been identified in the skills of medium-range weather forecasts in the Pan American sector (Nogués-Paegle et al. 1998; Jones and Schemm 2000) and in the occurrence of extreme events of precipitation (Carvalho et al. 2004; Liebmann et al. 2004; Jones et al. 2004) and temperature (Cerne and Vera 2010). Misra (2005) showed a diurnal rectification of ISV over the SAMS region. A control experiment in which a regional climate model was nested into a GCM showed minimal intra-seasonal variance over the SAMS. The results from this regional model integration amplified the biases of the GCM, one of which is weak ISV variability. Anomaly nested integrations showed an appreciable improvement in the intra-seasonal variance (Figure 7). The CPTEC/COLA AGCM reproduced observed intraseasonal variability of the summer season over South America, including the north-south OLR dipole, which is related to the SACZ convection variability and the PSA pattern depicting the tropics/extra-tropics teleconnection mode (Cunningham and Cavalcanti 2006). However, the model did not show the propagation of the OLR anomalies from Indonesia and the western Pacific eastward in the tropical region, typical of MJO.

The simulated inter-annual variability demonstrates good predictability in most models in eastern Amazonia and northern South America, as well as in the northeast region, which shows high positive anomaly correlations and convergence among ensemble members. However, model skill tends to be very low for the central and southeastern areas of the monsoon system. In these areas, there is large dispersion among ensemble members, which reduces confidence in the results. In fact, several two-tier AGCM experiments (Cavalcanti et al. 2002a) show negative correlations between observed and simulated summer rainfall anomalies over the SACZ area at inter-annual time scales.

Grimm et al. (2007b) examined the modes of interannual precipitation variability for spring and summer obtained from the CPTEC/COLA AGCM seasonal simulations for 23 years with observed SST as a boundary condition. Although the first modes for spring and summer are dipole-like, as observed, the northern part of the dipole in spring is displaced too far north. The relationship observed between these first modes in spring and summer, previously described in Section 6 (Grimm and Zilli 2009), is not reproduced by the model. This model failure might be due to the inability of the model to reproduce surface-atmosphere interactions.

One aspect of particular interest in this regard is the importance of ocean-atmosphere feedbacks in SSTcloud-solar radiation, as suggested by Chaves and Nobre (2004). The importance of ocean-atmosphere feedbacks over the SW tropical Atlantic for the SACZ dynamics was also highlighted in coupled ocean-atmosphere modelling studies by Misra (2008a).

The main atmospheric characteristics related to the SALLJ have been simulated by both global and regional models (Berbery and Collini 2000; Saulo et al. 2000; Cavalcanti et al. 2002b; Rozante and Cavalcanti 2008). The interaction between tropical and extra-tropical regions over South America through the SALLJ has been identified in climatological simulations (Rodriguez and Cavalcanti 2006). The variety of mechanisms forcing the low-level wind current from tropical to extra-tropical 
(a)

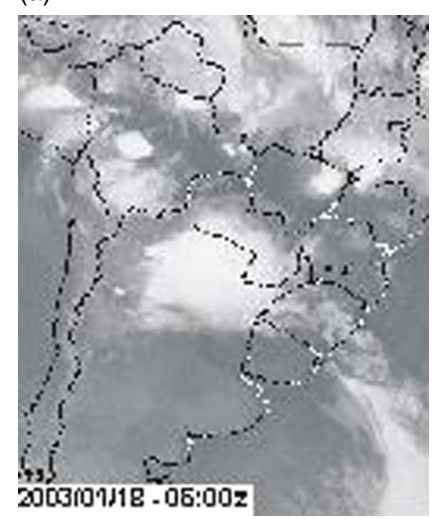

(b)

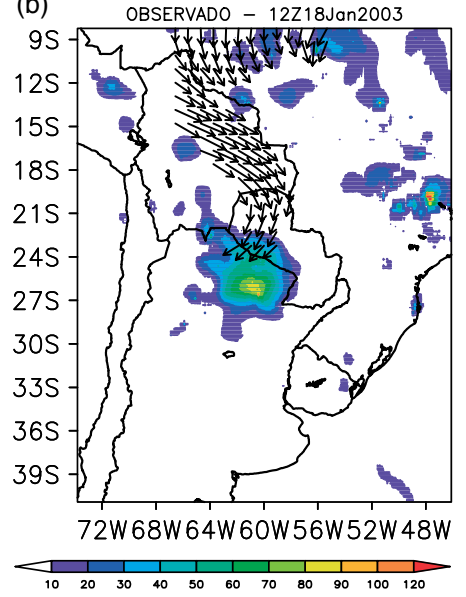

(c)

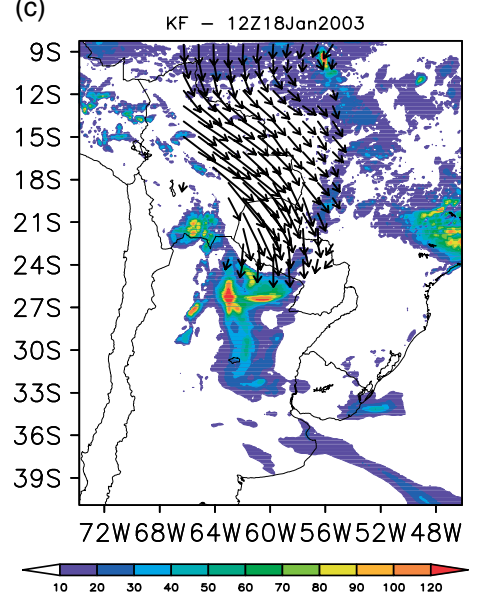

Figure 11. The MCS on 18 Jan 2003 which occurred during SALLJEX, was well simulated by the Eta model with KF convection scheme. (a) Infrared satellite image; (b) observed precipitation and reanalyses 850-hPa wind vector; and (c) simulated precipitation and wind vector from Eta regional model at $10 \mathrm{~km}$ resolution. (Source: Rozante and Cavalcanti 2008). This figure is available in colour online at wileyonlinelibrary.com/journal/joc

latitudes are represented by a regional model (Saulo et al. 2004), which also provide a useful depiction of the diurnal cycle of precipitation associated with strong SALLJ events (Nicolini and Saulo 2006).

The impact of changes in soil moisture in sub-tropical Argentina on rainfall distribution and low-level circulation were studied with a state-of-the-art regional model in a downscaling mode by Saulo et al. (2010). They used different scenarios of soil moisture for a case study with a well defined northwestern Argentinean low and a strong CJE event. It was found that land-surface interactions are stronger when soil moisture is decreased, with a consequent reduction of precipitation over southern South America. Changes in soil moisture and vegetation in modelling experiments can indicate changes in precipitation, temperature, and atmospheric circulation. The impact on South America precipitation in a regional model soil moisture initialisation was discussed by de Gonçalves et al. (2006a, b) using the South American Land Date Assimilation System (SALDAS). Other implementations of estimated soil moisture initialisation have been conducted at CPTEC with both regional and global models (Gevaerd and Freitas 2006).

MCS over northern Argentina and Paraguay associated with the SALLJ were also simulated by the regional Eta model at high resolution (Rozante and Cavalcanti 2008). It was found that the model at $10 \mathrm{~km}$ resolution with the Kain-Fritsch convection scheme, estimated soil moisture, and a non-hydrostatic version of the Eta model was the best in simulating the characteristics associated with the development of convection, such as the upper level jet, the SALLJ, humidity, and associated mechanisms for ascending motion, with $72 \mathrm{~h}$ in advance. One of these episodes of intense MCS during SALLJEX, which occurred on 18 January 2003, is illustrated in Figure 11. Features of the high-level jet, which forces a secondary circulation, and the convergence of humidity flux in the exit region of SALLJ, associated with the MCS development, discussed in Salio et al. (2007), were also well reproduced by the model.

Land use/cover change and aerosols from biomass burning are important forcings that are inherently regional in scope, and still some uncertainty is present in the responses and feedbacks of the climate system to emissions as represented in climate models. These uncertainties are related to the model representation of the conversion of emissions into concentrations of radiatively active species (via atmospheric chemistry and carboncycle models) and the subsequent response of the physical climate system. In turn, the latter uncertainties result from the representation of resolved processes (e.g. moisture advection), the parameterisations of sub-grid-scale processes (e.g. clouds, precipitation), and feedback mechanisms on the global and regional scale (e.g. changes in land-use/cover affecting the atmosphere, and the role of aerosols in the rainy season in Amazonia). A summary of these issues can be found in Cavazos et al. (2008). The long-term variations of the models' skills represent an additional source of uncertainty and indicate that the regional reliability of long climate model runs may depend on the time slice in which the output of the model is analysed (Grimm et al. 2006).

Obtaining accurate observational estimates of surface quantities such as soil moisture and evapotranspiration which can be used to validate model simulations, is a crucial aspect of improving the understanding of the South American climate. The low predictability of monsoon rainfall anomalies in central-east Brazil during the austral summer might be partially ascribed to the model's inability to reproduce well the topographical features and land-atmosphere interactions that are important for variability in the region (Grimm et al. 2007a).

Another important modelling issue is related to the model's ability in reproducing the influence of aerosols released by biomass burning in tropical South America. Aerosols can affect the radiation and energy budget and should be considered in modelling simulations. 
Monitoring of biomass burning over tropical South America using a regional model shows that the pollutants are transported southward by the mean flow and can affect areas of SESA (Freitas et al. 2004).

There are several modelling/data assimilation issues that arise not only from the above mentioned research, but also from other scientific questions introduced in the MESA Science and Implementation Plan (www.clivar. org/vamos). The inability of global models to capture important details of regional circulation patterns in the SAMS, as well as rainfall and convection simulation, has prompted regional-scale field experiments in the Amazon-SAMS regions, including the LBA WET AMC in 1999-2000 (Silva Dias et al. 2002) and SALLJEX during 2002-2003 (Vera et al. 2006a). They have provided a new set of field data that has been used for model inter-comparisons of some specific weather events during SALLJEX (Rozante and Cavalcanti 2008), or for data assimilation in the simulation of some selected SALLJ episodes during SALLJEX (Cavalcanti and Herdies 2004). Herdies et al. (2007) showed that the vertical structure of the meridional wind in the analyses was much closer to observed rawinsonde profiles in the experiments that included SALLJEX data than in the control experiments. The results show that, although there are more pilot balloon observations than rawinsonde observations in the SALLJEX dataset, most of the improvements in the analyses are obtained by inclusion of rawinsonde observations. The results of this study can serve as a benchmark for similar data impact studies using higherresolution data assimilation systems.

An important area of research is the design of metrics to test the ability of models to simulate well observed features of the current climates. The addition of such metrics provides guidance about the overall strengths and weaknesses of individual models, as well as of the general state of modelling.

\section{Societal applications}

In a globalised economy, improving our understanding of regional climate predictions and projections becomes very relevant, especially when a large area such as South America is involved. A slump in the production of soybean, corn, or sugarcane production in South America as a result of climate anomalies would have huge implications on the global market.

The SAMS region hosts the upper basins of many important rivers in South America such as the ParanaLa Plata and the Sao Francisco, and rainfall anomalies in the region translate into hydrological extremes. Drought and floods have devastating economic impacts on insured or underinsured individuals and corporates as well as on the insurance companies themselves. Floods take human lives and drought may cut off entire cities from their water sources, causing major economic damage. Alteration of water resources may lead to societal unrest and population relocation. A poor, or extremely wet rainy season or droughts, have a devastating effect on crops and hydroelectric generation. With the persistent reduction of precipitation in certain areas, lakes dry up, river flow decreases, and the fresh water supply is reduced, overwhelming available conservation options and depleting fresh water reserves.

The Sao Francisco, the Parana-La Plata, and some of the major tributaries of the Amazon River are essential to hydroelectric generation in major cities such as Sao Paulo, Rio de Janeiro, and Brasilia. Thus, delays in the onset of the rainy season and rainfall deficiency during the peak season may be extremely costly for the region's economy.

As an example, rainfall deficits during summer and fall 2001 resulted in a significant reduction in river flow throughout northeast, central-west and southeast Brazil, including the SAMS region, thereby reducing the capacity to produce hydroelectric power in these areas. Ninety percent of Brazil's energy is provided by hydroelectric systems. The large-scale nature of the deficits, which affected nearly the entire country, resulted in an energy crisis that forced the government to impose energy conservation measures in order to avoid total loss of power (blackouts) during parts of 2001 and 2002 (Cavalcanti and Kousky 2004; Drumond and Ambrizzi 2005).

In 2005, large sections of southwestern Amazonia experienced one of the most intense droughts of the last 100 years. The drought severely affected human populations along the main channel of the Amazon River and its western and southwestern tributaries. The Solimões River levels fell to historic lows. Navigation was suspended, isolating small villages and affecting tourism along the Solimões and Madeira Rivers (Marengo et al. 2008; Zeng et al. 2008; Cox et al. 2008). In 2009, intense floods affected the same region; Rio Negro in Manaus reached the highest level during 106 years of record. Estimates of the cost of these events are still under analysis.

The sensitivity of the SAMS region to weather and climate anomalies suggest that climate variability and change will have strong social repercussions in this region. A relatively small number of studies deal with climate-change impacts on natural ecosystems, agribusiness, renewable energies, water resources, megacities, and human health in the SAMS region. Events like the droughts of 2001 and 2005 may become more frequent or intense. Shorter soil moisture residence times, increases in the frequency and intensity of droughts, and rainy periods with more concentrated and intense rainfall events are likely to diminish soil water availability in this region. This would lead to a scenario of accelerating desertification and will further marginalise dryland agriculture, which is the current way of subsistence for many inhabitants of this region.

International initiatives such as the La Plata Basin Program (LPB, Berbery et al. 2005) and the EuropeSouth America Network for Climate Change Assessment and Impact Studies-CLARIS LPB project (www.clariseu.org) are directed to identify and describe the main climate and hydrological features of the La Plata Basin. 
CLARIS-LPB aims at predicting the regional climatechange impacts on La Plata Basin and at designing adaptation strategies for land use, agriculture, rural development, hydropower production, river transportation, water resources, and ecological systems in wetlands. The hydroclimate system of the La Plata Basin presents several challenges that have become apparent along the years; from vulnerability to floods and droughts to efficiency of hydropower production.

These international programs on LPB, in addition to other ongoing large-scale projects such as LBA and VAMOS-related programs, will allow for a better knowledge of the climatological and hydrological factors determining the frequency of occurrence and spatial extent of floods and droughts; the predictability of regional weather and climate variability and its impact on hydrological, agricultural and social systems of the basin; and the impacts of global climate change and land use change on regional weather, climate, hydrology, and agriculture.

\section{Future challenges and research needs}

Along with the significant progress already made particularly during the last years, some obstacles have been identified in the development of research related to MESA. Obstacles that may affect the progress of a research agenda in the SAMS region include: (1) the decay of the observational network; (2) the current profile of model and parameterisation development; and (3) lack of adequate computer facilities for the sensitivity testing to understand complex processes and their feedbacks. Testing the spatial resolution and temporal resolution and physics dependencies should be considered a grand challenge to the modelling community in terms of scientific effort and computing.

In the context of achievements of MESA and VAMOS as WCRP CLIVAR panels, and based on the review of published literature on various aspects of the SAMS characteristics and functioning during recent years, we have identified the following aspects that have emerged in recent studies as relevant to 3-dimensional description of the low circulation east of the Andes: (1) mesoscale convective processes; (2) role of aerosols from biomass burning due to land use change in the SAMS; (3) dynamics of the South American see-saw pattern; (4) ITCZ-SACZ interaction; (5) summertime convection and circulation over the Altiplano (Central Andes); (6) influence of MJO on the SAMS; (7) relative roles of remote and local forcing (SST, land surface, topography); and (8) land surface forcing - impacts of land use change.

Grand questions on SAMS that need to be explored in greater detail include the following: (1) what is the interaction between the SAMS and the stratocumulus cloud deck over the SE Pacific? (2) what are the relative roles of internal versus forced low-frequency variability? (3) what is the global response to SAMS forcing? (4) what are the sources and limits of predictability in the SAMS region? (5) is there predictability at decadal time scales? (6) what will be the functioning of SAMS in the future? Will it be more or less predictable? (7) what will be the impacts of aerosols and changes of atmospheric composition on SAMS's circulation and rainfall patterns? And (8) what are the uncertainties in SAMS's future climate change projections?

The answers to these questions will be revealed by combining intensive observational monitoring data with a modelling strategy directed towards a more realistic simulation on depiction and characteristics and variability of SAMS in various time scales. This will also lead to better projections of future climate change scenarios with uncertainty quantifications.

\section{Acknowledgements}

We would like to thank the National Institute of Science and Technology-Climate Change (INCT-Mudanças Climáticas) from the Brazilian Ministry of Science and Technology MCT, the UK Global Opportunity Fund-GOF Dangerous Climate Change (DCC) project. This work was partially supported by NOAA Grant ANA07OAR4310221. I. Cavalcanti, A. M. Grimm. T. Ambrizzi, and J. A. Marengo have received funding from CNPq (Brazilian National Council for Scientific and Technologic Development), and from the European Community's Seventh Framework Programme (FP7/20072013) under Grant Agreement No. 212492 (CLARIS LPB-A Europe-South America Network for Climate Change Assessment and Impact Studies in La Plata Basin). Additional thanks go to Ms. Meredith Field and Kathy Fearon of COAPS, FSU for her editorial assistance with this manuscript. All authors are members of the MESA Science Working Group.

\section{References}

Alexander LV, Zhang X, Peterson TC, Caesar J, Gleason B, Klein Tank AMG, Haylock M, Collins D, Trewin B, Rahimzadeh F, Tagipour A, Rupa Kumar K, Revadekar J, Griffiths G, Vincent L, Stephenson DB, Burn J, Aguilar E, Brunet M, Taylor M, New M, Zhai P, Rusticucci M, Vazquez-Aguirre JL. 2006. Global observed changes in daily climate extremes of temperature and precipitation. Journal of Geophysical Research-Atmospheres 111(D5): DOI:10.1029/2005JD006290.

Almeida RAF, Nobre P, Haarsma RJ, Campos EJD. 2007. Negative ocean-atmosphere feedback in the South Atlantic Convergence Zone. Geophysics Research Letters 34: L18809, DOI:10.1029/2007GL030401.

Ambrizzi T, Souza EB, Pulwarty RS. 2004. The Hadley and Walker regional circulation and associated ENSO impacts on South American seasonal rainfall. The Hadley Circulation: Present, Past and Future. Diaz HF, Bradley RS (eds) Kluwer Academic Publishers: Dordrecht, 203-235.

Berbery EH, Collini EA. 2000. Springtime precipitation and water vapor flux over Southeastern South America. Monthly Weather Review 128: 1328-1346.

Berbery EH, Barros V. 2002. The hydrological cycle of the La Plata Basin in South America. Journal of Hydrometrology 3: 630-645.

Berbery EH, Silva Dias MA, Baethgen W, Barros V, Collischonn W, Failache N, Lettenmaier D, Marengo J, Menendez A, Monte Domecq R, Moraes O, Morales C, Paruelo J, Seluchi M, Silva Dias P, Terra R, Ereño C, Meitín J, Coutinho H, Dias NL, Jobbágy E, Rocha H, Vera CS, Williams S. 2005. La Plata Basin (LPB) Continental Scale Experiment - Implementation Plan. Available from http://www.eol.ucar.edu/projects/lpb/ 
Betts R, Cox PM, Collins M, Arris PP, Huntingford C, Jones CD. 2004. The role of ecosystem-atmosphere interactions in simulated Amazonian precipitation decrease and forest die back under global climate warming. Theoretical and Applied Climatology 78: 157-166.

Betts RA, Malhi Y, Roberts JT. 2008. The future of the Amazon: new perspectives from climate, ecosystem and social sciences. Philosophical Transactions Royal Society of the Royal Society of London, Series B 363: 1729-1735.

Bombardi RJ, Carvalho LMV. 2009. IPCC Global coupled climate model simulations of the South America Monsoon System. Climate Dynamics 33: 893-916, DOI:10.1007/s00382-008-0488-1.

Bombardi RJ, Carvalho LMV. 2010. The South Atlantic dipole and variations in the characteristics of the South American Monsoon in the WCRP-CMIP3 multimodel simulations. Climate Dynamics, DOI: 10.1007/s00382-010-0836-9.

Boulanger JP, Martinez F, Segura EC. 2007. Projection of future climate change conditions using IPCC simulations, neural networks and Bayesian statistics. Part 2: Precipitation mean state and seasonal cycle in South America. Climate Dynamics 28: 255-271.

Carvalho LMV, Jones C, Liebmann B. 2002. Extreme precipitation events in Southeastern South America and large-scale convective patterns in South Atlantic Convergence Zone. Journal of Climate 15: $2377-2394$.

Carvalho LMV, Jones C, Liebmann B. 2004. The South Atlantic Convergence Zone: intensity, form, persistence, relationships with intraseasonal to interannual activity and extreme rainfall. Journal of Climate 17: 88-108.

Carvalho L, Jones C, Silva AE, Liebmann B, Silva Dias P. 2010. The South American Monsoon System and the 1970s climate transition. International Journal of Climatology, DOI:10.1002/joc.2147.

Cavalcanti IFA, Marengo JA, Satyamurty P, Nobre CA, Trosnikov I, Bonatti JP, Manzi AO, Tarasova T, Pezzi LP, D'Almeida C, Sampaio G, Castro CC, Sanches MB, Camargo H. 2002a. Global climatological features in a simulation using CPTEC/COLA AGCM. Journal of Climate 15: 2965-2988.

Cavalcanti IFA, Sousa CA Kousky VE. 2002b. The Low Level Jet east of Andes in the NCEP/NCAR reanalysis and CPTEC/COLA simulations. Conference on South American Low Level Jet, Sta Cruz de la Sierra (www-cima.at.fcen.uba.ar/sallj/sallj_conf_extabs.html

Cavalcanti IFA, Herdies D. 2004. Data Assimilation Study using SALLJEX Data. CLIVAR Exchanges 9(1): 23-26.

Cavalcanti IFA, Kousky VE. 2004. Drought in Brazil during Summer and Fall 2001 and associated atmospheric circulation features. Revista Climanálise Ano 2(01): (http://climanalise.cptec.inpe.br/ $\sim$ rclimanl/revista/pdf/criseing.pdf

Cavalcanti IFA, Camilloni I, Ambrizzi T. 2006. Escenarios Climaticos Regionales. Chapter 13 in El Cambio Climatico en la Cuenca del Plata. Barros V, Clarke R, Silva Dias P (eds). Buenos Aires, CONICET 2006. pp. 232.

Cavalcanti IFA, Cunningham CC. 2006. The wave four intraseasonal variability in extratropical S.H. and influences over South America. $8^{\text {th }}$ Southern Hemisphere International Conference on Meteorology and Oceanography. Foz do Iguaçu.

Cavazos T, Gochis D, Marengo JA, Boulanger JP. 2008. VAMOS and anthropogenic climate change in the Americas. Report of the VAMOS ACC task force, pp. 24 http://www.clivar.org/organization/ vamos/Publications/VAMOS_ACC_12Nov2008.pdf

Cazes-Boezio G, Robertson A, Mechoso CR. 2003. Seasonal Dependence of ENSO Teleconnections over South America and Relationships with Precipitation in Uruguay. Journal of Climate 16: 1159-1176

Cerne B, Vera CS. 2010. Influence of the intraseasonal variability on heat waves in subtropical South America. Climate Dynamics, DOI: 10.1007/s00382-010-0812-4.

Chase TN, Knaff JA, Pielke PA Sr, Kalnay E. 2003. Changes in global monsoon circulation since 1950. Natural Hazards 29: 229-254.

Chaves RR, Nobre P. 2004. Interactions between sea surface temperature over the South Atlantic Ocean and the South Atlantic Convergence Zone. Geophysical Research Letters, 31(3): L0320410.1029/2003GL018647.

Chiessi C, Mulitza S, Pätzold J, Wefer G, Marengo JA. 2009. Impact of the Atlantic Multidecadal Oscillation on the South American summer 1 monsoon, Geopysical Research Letters 36: L21707, DOI: 10.1029/2009GL039914.

Ciffelli R, Petersen WA, Carey LD, Rutledge SA. 2002. Radar observations of kinematics, microphysical, and precipitation characteristics of two MCSs in TRMM-LBA, Journal of Geophysical Research. 107: 10.1029/JD000264.
Coe MT, Costa MH, Soares-Filho BS. 2009. The influence of historical and potential future deforestation on the stream flow of the Amazon River - Land surface processes and atmospheric feedbacks. Journal of Hydrology 369: 165-174.

Collini EA, Berbery EH, Barros V, Pyle M. 2008. How Does Soil Moisture Influence the Early Stages of the South American Monsoon? Journal of Climate 21: 195-213.

Cox P, Betts R, Collins M, Harris P, Huntingford C, Jones C. 2004. Amazonian forest dieback under climate-carbon cycle projections for the 21th century. Theoretical and Applied Climatology 78: 137-156.

Cox P, Harris P, Huntingford C, Betts R, Collins M, Jones C, Jupp T, Marengo J, Nobre C. 2008. Increasing risk of Amazonian Drought due to decreasing aerosol pollution. Nature 453: 212-216.

Cunningham CC, Cavalcanti IFA. 2006. Intraseasonal modes of variability affecting the South Atlantic Convergence Zone. International Journal of Climatology 26(9): 1165-1180.

Da Rocha RP, Morales CA, Cuandra SV, Ambrizzi T. 2009. RegCM3 assessment over South America: Summer seasonal climatology and preciptation diurnal cycle. Journal of Geophysical Research 114 D10108, DOI: 10.1029/2008JD010212.

De Gonçalves LGG, Shuttleworth WJ, Burke EJ, Houser P, Toll DL, Rodell M, Arsenault K. 2006a. Toward a South America Land Data Assimilation System: Aspects of land surface model spin-up using the Simplified Simple Biosphere, Journal of Geophysical Research 111: D17110, DOI:10.1029/2005JD006297.

De Gonçalves LGG, Shuttleworth WJ, Nijssen B, Burke EJ, Marengo JA, Chou SC, Houser P, Toll DL. 2006b. Evaluation of model-derived and remotely sensed precipitation products for continental South America, Journal of Geophysical Research 111: D16113, DOI:10.1029/2005JD006276.

Doyle ME, Barros VR. 2002. Midsummer low-level circulation and precipitation in subtropical South America and related sea surface temperature anomalies in the South Atlantic. Journal of Climate 15: 3394-3410.

Drumond ARM, Ambrizzi T. 2005. The role of SST on the South American atmospheric circulation during the January, February and March 2001. Climate Dynamics 24: 781-791.

Durkee JD, Mote TL. 2009. A climatology of warm-season mesoscale convective complexes in subtropical South America. International Journal of Climatology. Published online in Wiley InterScience, (www.interscience.wiley.com), DOI:10.1002/joc.1893.

Durkee JD, Mote TL, Shepherd M. 2009. The Contribution of Mesoscale Convective Complexes to Rainfall across Subtropical South America. Journal of Climate 22: 4590-4605.

Falvey M, Garreaud R. 2004. Variability of Moisture and Convection over the Central Andes during SALLJEX. CLIVAR Exchanges 29(9): $11-13$.

Ferraz SET, Grimm AM. 2004. Intraseasonal variability in Summer: modulation by the interdecadal variability. Proceedings of the 13th Brazilian Meteorological Congress, Fortaleza: Brazil, Brazilian Meteorological Society.

Freitas SR, Longo KM, Silva Dias MAF, Silva Dias PL, Chatfield R, Prins E, Artaxo P, Recuero F. 2004. Monitoring the transport of biomass burning emissions in South America. Environmental Fluid Mechanics 5(1): 135-167, DOI:10.1007/s10652-005-0243-7.

Freitas SR, Longo KM, Silva Dias MAF, Chatfield R, Silva Dias P, Artaxo P, Andreae MO, Grell G, Rodrigues LF, Fazenda A, Panetta J. 2009. The Coupled Aerosol and Tracer Transport model to the Brazilian developments on the Regional Atmospheric Modeling System (CATT-BRAMS). Part 1: Model description and evaluation. Atmospheric Chemistry and Physics (online) 9: pp. 2843-2861.

Fu R, Zhu B, Dickinson RE. 1999. How do atmosphere and land surface influence seasonal changes of convection in the tropical Amazon? Journal of Climate 12: 1306-1321.

Gan MA, Kousky VE, Ropelewski CF. 2004. The South America monsoon circulation and its relationship to rainfall over west-central Brazil. Journal of Climate 17: 47-66.

Gan MA, Rao VB, Moscati MCL. 2006. South American monsoon indices. Atmospheric Science Letters 6: 219-223.

Gan MA, Rodrigues LR, Rao VB. 2009. Monção na America do Sul. Chapter 19 in Tiempo y Clima no Brasil, Cavalcanti I, Ferreira NJ, Justi MAG, Silva Dias MAF, (eds) Editora. Oficina de Textos, São Paulo: Brazil, pp. 297-312.

Garcia SR, Kayano MT. 2008. Some evidence on the relationship between the South American monsoon and the Atlantic ITCZ, Theoretical and Applied Climatology, DOI:10.1007/s00704-0090107-z.

Garcia SR, Kayano MT. 2009. Determination of the onset dates of the rainy season in central Amazon with equatorially antisymmetric 
outgoing longwave radiation. Theoretical and Applied Climatology 97: $361-372$.

Garreaud RD. 1999. Multi scale analysis of the summertime precipitation over the Central Andes. Monthly Weather Review 127: 901-921.

Gevaerd R, Freitas S. 2006. Estimativa operacional de umidade do solo para iniciação de modelos de previsão numérica da atmosfera. Revista Brasileira de Meteorologia Volume Especial da LBA (www.cptec.inpe.br/brams/papers/soilmoisture_Gevaerd\&Freitas_ RBMET2006.pdf)

Gonzalez M, Vera C, Liebmann B, Marengo J, Kousky V, Allured D. 2007. The nature of the rainfall onset over central South America Atmósfera 20(4): 379-396.

Grimm A, Ferraz SET. 2002. Interdecadal variations of the relationship between ENSO and precipitation over Brazil. Proceedings of the 12th Brazilian Meteorological Congress, Foz do Iguaçu, Brazil, Brazilian Meteorological Society.

Grimm AM. 2003. The El Nino impact on the summer monsoon in Brazil: Regional processes versus remote influences. Journal of Climate 16: 263-280.

Grimm AM. 2004. How do La Niña events disturb the summer monsoon system in Brazil? Climate Dynamics 22(2-3): 123-138.

Grimm AM, Vera C, Mechoso R. 2005. The South American Monsoon System, Chang C-P, Wang B, Lau NC-G, (eds) The Global Monsoon System: Research and Forecast, WMO/TD 1266 - TMRP: pp. 542 Available at http://www.wmo.int/pages/prog/arep/tmrp/documents/ global_monsoon_system_IWM3.pdf

Grimm A, Natori A. 2006. Climate change and interannual variability of precipitation in South America. Geophysical Research Letters 33 L19706, DOI:10.1029/2006GL026821.

Grimm AM, Sahai AK, Ropelewski CF. 2006. Interdecadal Variations in AGCM Simulation Skills. Journal of Climate 19: 3406-3419.

Grimm A, Pal J, Giorgi F. 2007a. Connection between Spring Conditions and Peak Summer Monsoon Rainfall in South America: Role of Soil Moisture, Surface Temperature, and Topography in Eastern Brazil. Journal of Climate 20: 5929-5945.

Grimm AM, Zilli MT, Cavalcanti IF. 2007b. Do seasonal forecasts reproduce the link between early and peak monsoon rainfall in South America? CLIVAR Exchanges 12(4): pp. 16-20.

Grimm A, Zilli MT. 2009. Interannual variability and seasonal evolution of summer monsoon in South America. Journal of Climate 22: 2257-2275.

Grimm AM, Tedeschi RG. 2009. ENSO and extreme rainfall events in South America. Journal of Climate 22: 1589-1609.

Grimm AM, Ambrizzi T. 2009. Teleconnections into South America from the tropics and extratropics on interannual and intraseasonal timescales. In: Past Climate Variability in South America and Surrounding Regions: From the Last Glacial Maximum to the Holocene, Developments in Paleoenvironmental Research Vimeux F, Sylvestre F, Khodri M, (eds). Springer: Netherlands, 159-191, DOI: 10.1007/978-90-481-2672-9.

Grimm AM. 2010. Interannual climate variability in South America: impacts on seasonal precipitation, extreme events and possible effects of climate change. Stochastic Environmental Research and Risk Assessment, DOI: 10.1007/s00477-010-0420-1.

Grimm AM, Silva Dias MAF. 2010. Synoptic and Mesoscale Processes in the South American Monsoon. In The Global Monsoon System: Research and Forecast, Chang CP, Ding Y, Johnson RH, Lau G, Wang B, Yasunari Y (eds.) World Scientific Publication Company: Singapore, 239-255.

Haylock MR, Peterson T, Abreu de Sousa JR, Alves L, Ambrizzi T, Baez J, Barbosa de Brito J, Barros VR, Berlato MA, Bidegain M, Coronel G, Corradi V, Garcia T, Grimm AM, Jaildo dos Anjos R, Karoly D, Marengo JA, Marino MB, Meira PR, Miranda GC, Molion LCB, Muncunil D, Nechet D, Ontaneda G, Quintana J, Ramirez E, Rebello E, Rusticucci M, Santos JL, Varillas IT, Vincent L, Yumiko M. 2006. Trends in total and extreme South American rainfall 1960-2000 and links with sea surface temperature. Journal of Climate 19: 1490-1512.

Herdies DL, Kousky V, Ebisuzaki W. 2007. The Impact of HighResolution SALLJEX Data on Global NCEP Analyses. Journal of Climate 20: $5765-5783$.

Jones C, Schemm J. 2000. The Influence of Intraseasonal Variations on Medium- to Extended-Range Weather Forecasts over South America. Monthly Weather Review 128: 486-494.

Jones C, de Carvalho LMV. 2002. Active and break phases in the South American Monsoon System. Journal of Climate 15: 905-914.
Jones C, Waliser DE, Lau KM, Stern W. 2004. Global occurrences of extreme precipitation and the Madden-Julian oscillation: observations and predictability. Journal of Climate 17: 4575-4589.

Kim HJ, Wang B, Ding QH. 2008. The Global Monsoon Variability Simulated by CMIP3 Coupled Climate Models. Journal of Climate 21(20): 5271-5294.

Koster RD. 2004. Regions of strong coupling between soil moisture and precipitation. Science 305: 1138-1140.

Kousky VE. 1988. Pentad outgoing longwave radiation climatology for the South America sector. Revista Brasilera de Meteorología 3: 217-231.

Kunkel KE, Bromorski PD, Brooks HE, Cavazos T. 2008. Observed changes in weather and climate extremes in Weather and Climate Extremes in a Changing Climate, Karl TR, Meehl GA, Miller CD, Hassol SJ, Waple AM, Murray WL, (eds). A Report of the U. S. Climate Change Science Program: Washington, DC.

Laing AG, Fritsch JM. 2000. The large-scale environments of the global populations of mesoscale convective complexes. Monthly Weather Review 128: 2756-2776.

Li W, Fu R. 2004. Transition of the large-scale atmospheric and land surface conditions from the dry to the wet season over Amazonia as diagnosed by the ECMWF Re-Analysis. Journal of Climate 17: 2637-2651.

Li W, Fu R, Negrón Juárez RN, Fernandes K. 2008. Observed change of the standardised precipitation index, its potential cause and implications to future climate change in the Amazon region. Philosophical Transactions of the Royal Society of London, Series $B$ 363: $1767-1772$.

Liebmann B, Marengo J. 2001. Interannual variability of the rainy season and rainfall in the Brazilian Amazon Basin. Journal of Climate 14: 4308-4318.

Liebmann B, Jones C, Carvalho LMV. 2001. Interannual variability of extreme precipitation events in the state of São Paulo. Brazilian Journal of Climate 14: 208-218.

Liebmann B, Kiladis GN, Vera CS, Saulo AC, Carvalho LMV. 2004. Subseasonal variations of rainfall in South America in the vicinity of the low-level jet east of the Andes and comparison to those in the South Atlantic convergence zone. Journal of Climate 17: 3829-3842.

Liebmann B, Mechoso CR. 2010. The South American Monsoon System, Chapter 8 in The Global Monsoon System: Research and Forecast, 2nd Edition. C. P Chang et al., (eds.) World Scientific Publishing: Singapore. $550 \mathrm{p}$.

Liu Y-Q, Fu R, Dickinson R. 2005. Smoke aerosols altering South 373 American monsoon. Bulletin of the American Meteorological Society 86(8): $1062-1063$.

Malhi Y, Roberts JTR, Betts RA, Killeen TJ, Li W, Nobre CA. 2008. Climate change, deforestation, and the fate of the Amazon. Science, 319: 169-172, DOI:10.1126/science. 1146961.

Malhi Y, Aragäo LEOC, Galbraith D, Huntingford C, Fisher R, Zelazowski P, Sitch S, McSweeney C, Meir P. 2009. Exploring the likelihood and mechanism of a climate-change-induced dieback of the Amazon rainforest. PNAS 106(49): pp. 20610-20615, DOI:10.1073/pnas.0804619106.

Marengo JA, Liebmann B, Kousky VE, Filizola NP, Wainer IC. 2001. Onset and end of the rainy season in the Brazilian Amazon basin. Journal of Climate 14: 833-852.

Marengo JA. 2004. Interdecadal and long term rainfall variability in the Amazon basin. Theoretical and Applied Climatology 78: 79-96.

Marengo JA, Fisch G, Morales C, Vendrame I, Dias PC. 2004a. Diurnal variability of rainfall in Southwest Amazonia during the LBA-TRMM field campaign of the Austral summer of 1999. Acta Amazonica 34(4): 593-603.

Marengo JA, Soares W, Saulo W, Nicolini M. 2004b. Climatology of the LLJ east of the Andes as derived from the NCEP reanalyses. Journal of Climate 17: 2261-2280.

Marengo JA, Nobre C, Tomasella J, Oyama M, Sampaio G, Camargo H, Alves L, Oliveira R. 2008. The drought of Amazonia in 2005. Journal of Climate 21: 495-516.

Marengo JA, Jones R, Alves LM, Valverde MC. 2009a. Future change of temperature and precipitation extremes in South America as derived from the PRECIS regional climate modeling system. International Journal of Climatology 15: 2241-2255.

Marengo JA, Ambrizzi T, Rocha RP, Alves LM, Cuadra SV, Valverde MC, Ferraz SET, Torres RR, Santos DC. 2009b. Future change of climate in South America in the late XXI Century: Intercomparison of scenarios from three regional climate models, Climate Dynamics, Climate Dynamics, DOI:10.1007/s00382-0090721-6. 
Marengo JA, Rusticucci M, Penalba O, Renom M. 2009c. An intercomparison of observed and simulated extreme rainfall and temperature events during the last half of the twentieth century: part 2: historical trends. Climatic Change, DOI:10.1007/s10584-0099743-7.

Menon S, Hansen J, Nazarenko L, Luo Y. 2002. Climate effects of black carbon aerosols in China and India. Science 297: 2250-2253.

Misra V, Dirmeyer PA, Kirtman BP, Juang H-M, Kanamitsu M. 2002. Regional simulation of interannual variability over South America. Journal of Geophysical Research 107: 8036, DOI:10.1029/ 2001JD900216.

Misra V. 2005. Simulation of the intraseasonal variance of the South American summer monsoon. Monthly Weather Review 133(3): $663-676$.

Misra V. 2008a. Coupled air, sea, and land interactions of the South American Monsoon. Journal of Climate 21: 6389-6403.

Misra V. 2008b. Coupled interactions of the monsoons. Geophysical Research Letters 35: L12705, DOI:10.1029/2008GL033562.

Misra V. 2009. The amplification of the ENSO forcing over Equatorial Amazon. Journal of Hydrometeorology 16: 1561-1568.

Muza MN, Carvalho LMV, Jones C, Liebmann B. 2009. Intraseasonal and Interannual variability of Extreme Dry and Wet Events over Southeastern South America and Subtropical Atlantic during the Austral Summer. Journal of Climate 22: 1682-1699.

Nesbitt SW, Zipser E. 2003. The diurnal cycle of rainfall and convective intensity according to three years of TRMM measurements. Journal of Climate 16: 1456-1475.

Nicolini M, Salio P, Ulke G, Marengo J, Douglas M, Paegle J, Zipser E. 2004. South American Low Level Jet Diurnal cycle and Three Dimensional Structure. CLIVAR-Exchanges 9: 6-8.

Nicolini M, Saulo AC. 2006. Modeled Chaco low-level jets and related precipitation patterns during the 1997-1998 warm season. Meteorology and Atmospheric Physics 94(1-4): 129-143, DOI:10.1007/s00703-006-0186-7.

Nieto-Ferreira R, Rickenbach TM, Herdies DL, Carvalho LM. 2003. Variability of South American convective cloud systems and tropospheric circulation during January-March 1998 and 1999. Monthly Weather Review 131: 961-973.

Nieto-Ferreira R, Rickenbach TM. 2011. Regionality of monsoon onset in South America: a three-stage conceptual model. International Journal of Climatology 31: 1309-1321, DOI:10.1002/joc.2161.

Nieto-Ferreira R, Rickenbach TM, Wright EW. 2011. The role of cold fronts in the onset of the monsoon season in the South Atlantic convergence zone. Q. J. R. Meteorol. Soc. 137: 908-922, DOI: 10.1002/qj.810.

Nobre P, Malagutti M, Urbano DF, de Almeida RAF, Giarolla E. 2009. Amazon Deforestation and Climate Change in a Coupled Model Simulation. Journal of Climate 22: 5686-5697.

Nobre CA, Borma LS. 2009. Tipping points' for the Amazon forest. Current Opinion in Environment Sustainability 1: 28-36.

Nogués-Paegle J, Mo K. 1997. Alternating wet and dry conditions over South America during summer. Monthly Weather Review 125: 279-291.

Nogues-Paegle J, Mo K, Paegle J. 1998. Predictability of the NCEP-NCAR reanalysis model during austral summer. Monthly Weather Review 126: 3135-3152.

Nuñez MN, Solman SA, Cabré MF. 2008. Regional Climate change experiments over southern South America. II: Climate Change scenarios in the late twenty-first century. Climate Dynamics, DOI:10.1007/s00382-008-0449-8.

Paegle JN, Mo KC. 2002. Linkages between summer rainfall variability over South America and sea surface temperature anomalies. Journal of Climate 15: 1389-1407.

Penalba OC, Robledo F. 2010. Spatial and temporal variability of the frequency of extreme daily rainfall regime in the La Plata Basin during the 20th century. Climatic Change 98(3): 531-550.

Pitman AJ, de Noblet-Ducoudré N, Cruz FT, Davin EL, Bonan GB, Brovkin V, Claussen M, Delire C, Ganzeveld L, Gayler V, van den Hurk BJJM, Lawrence PJ, van der Molen MK, Müller C, Reick CH, Seneviratne SI, Strengers BJ, Voldoire A. 2009. Uncertainties in climate responses to past land cover change: first results from the LUCID intercomparison study. Geophysical Research Letters 36: L14814, DOI:10.1029/2009GL039076.

Pscheidt I, Grimm AM. 2009. Frequency of extreme rainfall events in Southern Brazil modulated by interannual and interdecadal variability. International Journal of Climatology 29: 1988-2011.

Raia A, Cavalcanti IFA. 2008. The Life Cycle of the South American Monsoon System. Journal of Climate 21: 6227-6246.
Robertson AW, Mechoso CR. 2000. Interannual and interdecadal variability of the South Atlantic Convergence Zone. Monthly Weather Review 128: 2947-2957.

Robertson AW, Farrara JD, Mechoso CR. 2003. Simulations of the atmospheric response to South Atlantic sea surface temperature anomalies. Journal of Climate 16: 2540-2551.

Rodriguez DA, Cavalcanti IFA. 2006. Simulations of the Hydrologic Cycle over Southern South America using the CPTEC/COLA AGCM. Journal of Hydrometeorology 7: 916-936.

Ropelewski CF, Bell MA. 2008. Shifts in the statistics of daily rainfall in South America conditional on ENSO phase. Journal of Climate 21: $849-865$.

Rozante JR, Cavalcanti IFA. 2008. Regional Eta model experiments. SALLJEX and MCS developments. Journal of Geophysical Research 113: D17106, DOI:10.1029/2007JD009566.

Rusticucci M, Marengo J, Penalba O, Renom M. 2009. An intercomparison of model-simulated in extreme rainfall and temperature events during the last half of the twentieth century. Part 1: mean values and variability. Climate Change, DOI:10.1007/s10584-009 9742-8.

Salazar LF, Nobre CA, Oyama MD. 2007. Climate change consequences on the biome distribution in tropical South America. Geophysical Research Letters 34: L09708.

Salio P, Nicolini M, Zipser EJ. 2007. Mesoscale convective systems over Southeastern South America and their relationship with the South American Low Level Jet. Monthly Weather Review 135: 1290-1309.

Sampaio G, Nobre CA, Costa MH, Satyamurty P, Soares-Filho BS, Cardoso M. 2007. Regional climate change over eastern Amazonia caused by pasture and soybean cropland expansion. Geophys. Res. Lett. 34: L17709, DOI: 10.1029/2007GL030612.

Satyamurty P, de Castro AA, Tota J, Gularte LE, Manzi AO. 2009. Rainfall trends in the Brazilian Amazon Basin in the past eigh decades, Theoretical and Applied Climatology, DOI:10.1007/s00704009-0133-x.

Saulo AC, Nicolini M, Chou SC. 2000. Model characterization of the South American low-level flow during the 1997-98 spring-summer season. Climate Dynamics 16: 867-881.

Saulo AC, Seluchi ME, Nicolini M. 2004. A Case Study of a Chaco Low-Level Jet Event. Monthly Weather Review 132: 2669-2683.

Saulo AC, Ferreira L, Nogués-Paegle J, Seluchi ME, Ruiz J. 2010. Land-Atmosphere Interactions during a Northwestern Argentina Low Event. Monthly Weather Review 138: 2481 -2498, DOI:10.1175/ 2010MWR3227.1.

Seth A, Rauscher S, Camargo S, Qian J-H, Pal J. 2006. RegCM regional climatologies for South America using reanalysis and ECHAM model global driving fields. Climate Dynamics, DOI:10.1007/s00382-006-0191-z.

Seth A, Rojas M, Rauscher S. 2010. CMIP3 projected changes in the annual cycle of the South American Monsoon Climatic Change 98: $331-357$.

Shiogama H, Watanabe M, Kimoto M, Nozawa T. 2005. Anthropogenic and natural forcing impacts on ENSO-like decadal variability during the second half of the 20th century. Geophysical Research Letters 32: L21714, DOI:10.1029/2005GL023871.

Silva AE, Carvalho LMV. 2007. Large-scale index for South America Monsoon (LISAM). Atmospheric Science Letters 8: 51-57.

Silva GAM, Ambrizzi T, Marengo JA. 2009. Observational evidences on the modulation of the South American Low Level Jet east of the Andes according the ENSO variability. Annales Geophysicae 27: 645-657.

Silva VBS, Berbery EH. 2006. Intense rainfall events affecting the La Plata basin. Journal of Hydrometeorology 7: 769-787.

Silva Dias MAF, Rutledge S, Kabat P, Silva Dias PL, Nobre CA, Fisch G, Dolman AJ, Zipser E, Garstang M, Manzi AO, Fuentes JD, da Rocha HR, Marengo JA, Plana-Fattori A, S'a LDA, Alval'a RCS, Andreae MO, Artaxo P, Gielow R, Gatti L. 2002. Cloud and rain processes in a biosphere-atmosphere interaction context in the Amazon Region. Journal of Geophysical Research 107: DOI:10.1029/2001JD000335.

Silvestri GE, Vera CS. 2003. Antarctic Oscillation signal on precipitation anomalies over southeastern South America. Geophysical Research Letters 30(21): DOI:10.1029/2003GL018277.

Silvestri G, Vera CS. 2009. Interdecadal variations of the Southern Annular Mode and its impact on South America. Journal of Climate 22: 6142-6148.

Siqueira LSP, Nobre P. 2006. Tropical Atlantic sea surface temperature and heat flux simulations in a coupled GCM. Geophysical Research Letters 33: $1-6$. 
Sitch S, Huntingford C, Gedney N, Levy PE, Lomas M, Piao SL, Betts R, Ciais P, Cox P, Friedlingstein P, Jones CD, Prentice IC, Woodward FI. 2008. Evaluation of the terrestrial carbon cycle, future plant geography and climate-carbon cycle feedbacks using five Dynamic Global Vegetation Models (DGVMs). Global Change Biology 14: 2015-2039.

Soares W, Marengo J. 2008. Assessments of moisture fluxes east of the Andes in South America in a global warming scenario. International Journal of Climatology Published online in Wiley InterScience (www.interscience.wiley.com), DOI:10.1002/joc.1800.

Souza EB, Ambrizzi T. 2006. Modulation of the intraseasonal rainfall over tropical Brazil by the Madden-Julian oscillation. International Journal of Climatology 26: DOI:10.1002/joc.1331.

Tanaka HL, Ishizaki N, Nohara N. 2005. Intercomparison of the Intensities and Trends of Hadley, Walker and Monsoon Circulations in the Global Warming Predictions. SOLA 1: 077-080.

Tebaldi C, Hayhoe K, Arblaster J, Meehl G. 2006. Going to the extremes: An intercomparison of model-simulated historical and future changes in extreme events. Climatic Change 79: 185-211, DOI:10.1007/s10584-006-9051-4.

Vendrasco E, Silva Dias PL, Freitas ED. 2009. A case study of the direct radiative effect of biomass burning aerosols on precipitation in the Eastern Amazon. Atmospheric Research 94: 409-421.

Vera CS, Silvestri G, Barros V, Carril A. 2004. Differences in El Niño response over the Southern Hemisphere. Journal of Climate 17: $1741-1753$.

Vera CS，Baez J，Douglas M，Emanuel C， Marengo JA， Meitin J,
Nicolini M, Nogues-Paegle J, Paegle J, Penalba O, Salio P, Saulo C, Silva Dias MAF, Silva Dias PL, Zipser E. 2006a. The South American Low-Level Jet Experiment. Bulletin of the American Meteorological Society 87: 63-77.

Vera CS, Higgins W, Amador J, Ambrizzi T, Garreaud R, Gochis D, Gutzler D, Lettenmaier D, Marengo JA, Mechoso CR, NoguesPaegle J, Silva Dias PL, Zhang C. 2006b. Toward a Unified View of the American Monsoon Systems. Journal of Climate 19: 4977-5000.

Vera CS, Silvestri G, Liebmann B, González P. 2006c. Climate change scenarios for seasonal precipitation in South America from IPCC-AR4 models. Geophysical Research Letters 33: L13707, DOI: 10.1029/2006GL025759.

Vera CS, Silvestri G. 2009. Precipitation interannual variability in South America from the WCRP-CMIP3 Multi-model dataset. Climate Dynamics 32: 1003-1014.

Wang B, Ding Q. 2006. Changes in global monsoon precipitation over the past 56 years. Geophysical Research Letters 33: L06711, DOI: $10.1029 / 2005$ GL025347.

Zeng N, Yoon J, Marengo JA, Subramaniam A, Nobre CA, Mariotti A. 2008. Causes and impacts of the 2005 Amazon drought. Environ. Res. Lett. 3: 1-9, DOI:10.1088/1748-9326/3/1/014002.

Zhou J, Lau WK-M. 2001. Principal modes of interannual and decadal variability of summer rainfall over South America. International Journal of Climatology 21: 1623-1644.

Zipser EJ, Cecil DJ, Liu C, Nesbitt SW, Yorty DP. 2006. Where are the most intense thunderstorms on earth? Bulletin of the American Meteorological Society 87: 1057-1071. 